\title{
The Metabolism of Starch, Maltose, Glucose and Some Other Sugars by the Rumen Ciliate Entodinium caudatum
}

\author{
By G. S. COLEMAN \\ Biochemistry Department, Agricultural Research Council, \\ Institute of Animal Physiology, Babraham, Cambridge
}

(Accepted for publication 19 April 1969)

\begin{abstract}
SUMMARY
Washed suspensions of Entodinium caudatum grown in vitro and incubated anaerobically incorporated ${ }^{14} \mathrm{C}$ from $\left[{ }^{14} \mathrm{C}\right]$ glucose into the cell pool as $\left[{ }^{14} \mathrm{C}\right]$ glucose, maltose and hexose phosphate and into protozoal polysaccharide and intracellular bacteria as a glucose polymer. The uptake of sugars into the pool was by an active process (predominant at low sugar concentrations) probably into the protozoal endoplasm, and by a passive process (predominant at high concentrations) into another part of the cell. Uptake of glucose by the active process was not sufficiently rapid to increase the level of glucose in the pool by more than $17 \%$ per hour; this was probably insufficient to increase appreciably the rate of glucose utilization. These protozoa hydrolysed starch to maltose and glucose and the level of these sugars in the pool of protozoa metabolizing starch grains was controlled in part by the inhibitory effect of these sugars on the enzymes that formed them. Studies on the enzymes involved in the metabolism of starch showed that the glucose in starch was hydrolysed to free glucose before phosphorylation. In experiments on the effect of carbohydrates on the survival of protozoa, starch was the most effective in prolonging protozoal life, followed by maltose and glucose in that order. The greater effectiveness of maltose was correlated with the finding that the rate of uptake of maltose carbon was always greater than that for glucose when the two sugars were present in equimolar concentrations. However, the rate for both sugars was markedly decreased in the presence of penicillin and neomycin. Evidence is presented that the protozoal ectoplasm may be freely permeable to sugars in the medium and that there is a barrier between the ectoplasm and endoplasm. ${ }^{14} \mathrm{C}$ from $\left[{ }^{14} \mathrm{C}\right]$ starch grains was incorporated by the protozoa but there was no synthesis of protozoal protein from carbohydrate.
\end{abstract}

\section{INTRODUCTION}

It has been known for many years (Sugden, I953; Abou Akkada \& Howard, I960) that rumen Entodiniomorphid protozoa do not readily metabolize sugars as determined by sugar disappearance, by acid or gas formation or by the synthesis of polysaccharide. In contrast, starch grains as can be engulfed by the protozoa are degraded to volatile fatty acids, hydrogen and $\mathrm{CO}_{2}$ (Abou Akkada \& Howard, 1960) and have been used as principal source of carbohydrate for the maintenance of Entodinium caudatum, in vitro, for over 8 years (Coleman, I960 a). However, there is evidence that this protozoon could metabolize sugars since the life of starved 'bacteria free' suspensions incubated in the presence of penicillin and neomycin could be prolonged by glucose, maltose and starch in increasing order of effectiveness (Coleman, 
1962). The present communication describes the metabolism of $\left[{ }^{14} \mathrm{C}\right]$ labelled starch and sugars by washed suspensions of Entodinium caudatum with special reference to the differential effect of glucose, maltose and starch on protozoal survival. There is a permeability barrier between the medium and the protozoal endoplasm and this barrier is more permeable to maltose than glucose and is crossed by starch grains following their engulfment.

\section{METHODS}

Source of protozoa. Entodinium caudatum was grown and inoculum cultures prepared and treated as described by Coleman (1962) except that inoculum cultures were treated each day with $\mathrm{I} \cdot 0 \mathrm{ml} .1 \cdot 5 \%$ rice starch suspension and about $10 \mathrm{mg}$. dried grass.

Preparation of protozoa for inoculation. The protozoa were present as a loose pellet at the bottom of the tube containing the inoculum cultures. After removal of the surface scum and most of the medium, the protozoa and remaining medium were transferred to $8 \times I$ in. $(20 \times 2.5 \mathrm{~cm}$.) tubes and allowed to stand until any grass present had sunk to the bottom, leaving the protozoa in the supernatant fluid. This supernatant fluid was transferred to centrifuge tubes, the residual grass washed with salt solution B (Coleman, $1960 b$ ) and the washings added to the supernatant fluid. The protozoa were spun down and washed four times in salt solution $B$ through which a gas mixture of $95 \%(\mathrm{v} / \mathrm{v}) \mathrm{N}_{2}+5 \%(\mathrm{v} / \mathrm{v}) \mathrm{CO}_{2}$ had been bubbled vigorously for 3 min., on a bucket-head centrifuge for $20 \mathrm{sec}$. from starting; the maximum speed was equivalent to $200 \mathrm{~g}$. The protozoa were finally used as an inoculum to give a population density of 5 to $15 \times 10^{5}$ protozoa $/ \mathrm{ml}$.

Incubation conditions for incorporation experiments. The medium consisted of 0.15 to $0.4 \mathrm{ml}$. [ ${ }^{14} \mathrm{C}$ ]sugar $(0.0025$ to $0.7 \mathrm{M}$ and 0.25 to $6.9 \mu \mathrm{c} / \mathrm{ml}$.), $\mathrm{I} \cdot 0 \mathrm{ml}$. protozoal inoculum (suspended in salt solution B through which $95 \%(\mathrm{v} / \mathrm{v}) \mathrm{N}_{2}+5 \%(\mathrm{v} / \mathrm{v}) \mathrm{CO}_{2}$ had been bubbled vigorously for $3 \mathrm{~min}$.), $0.2 \mathrm{ml}$. of any other additions and 0 to $0.45 \mathrm{ml}$. salt solution B (chosen so that the final volume was $1.5 \mathrm{ml}$.). Experiments were made in $4 \times 0.5 \mathrm{in}$. (10 $\times 1.3 \mathrm{~cm}$.) thick-walled test tubes and after inoculation were gassed with $95 \%(\mathrm{v} / \mathrm{v}) \mathrm{N}_{2}+5 \%(\mathrm{v} / \mathrm{v}) \mathrm{CO}_{2}$, sealed with a rubber bung and incubated at $39^{\circ}$, except where otherwise stated.

Incubation conditions for treatment with antibiotics. The medium consisted of $0.8 \mathrm{ml}$. penicillin G (25,000 units $/ \mathrm{ml}$.), $0.8 \mathrm{ml}$. I \% (w/v) neomycin sulphate and $20 \mathrm{ml}$. protozoal inoculum, all in a $100 \mathrm{ml}$. conical flask which was gassed with $95 \%(\mathrm{v} / \mathrm{v})$ $\mathrm{N}_{2}+5 \%(\mathrm{v} / \mathrm{v}) \mathrm{CO}_{2}$, sealed with a rubber bung and incubated at $39^{\circ}$. At the end of the incubation (usually $\mathrm{I} 8 \mathrm{hr}$ ) the protozoa were isolated as described previously.

Incubation conditions for experiments on protozoal survival. The medium consisted of 3.1 to $5.3 \mathrm{ml}$. (chosen so that the final volume was ro $\mathrm{ml}$.) salt solution B and $2.0 \mathrm{ml}$. water autoclaved ( $115^{\circ}$ for $20 \mathrm{~min}$.) in a $15 \mathrm{ml}$. centrifuge tube. Immediately after removal from the autoclave the following additions were made aseptically: $0.2 \mathrm{ml} . \mathrm{I} \%$ L-cysteine hydrochloride (neutralized and Seitz filtered), $0.2 \mathrm{ml} .5 \%(\mathrm{w} / \mathrm{v}) \mathrm{NaHCO}$ (Seitz filtered), $0.4 \mathrm{ml}$. penicillin G (25,000 units $/ \mathrm{ml}$ ), $0.4 \mathrm{ml}$. I \% (w/v) neomycin sulphate, I.0 ml. autoclaved rumen fluid (PARF; Coleman, 1964a) and 0 to $2 \cdot 2 \mathrm{ml}$. sugar solution (autoclaved at $115^{\circ}$ for $20 \mathrm{~min}$. in water) or soluble starch (autoclaved at $115^{\circ}$ for $20 \mathrm{~min}$. in salt solution B) or o to $0.3 \mathrm{ml} .7 .5 \%$ (w/v) rice starch (rice starch heated dry at $120^{\circ}$ for $24 \mathrm{hr}$ and suspended in sterile salt solution B). After inoculation 
to give a population density of approximately $5 \times 10^{5}$ protozoa $/ \mathrm{ml}$. the tubes were gassed with $95 \%(\mathrm{v} / \mathrm{v}) \mathrm{N}_{2}+5 \%(\mathrm{v} / \mathrm{v}) \mathrm{CO}_{2}$, sealed with a rubber bung and incubated at $39^{\circ}$. For each point on a time course a fresh culture was sampled and the tube then discarded.

Incubation conditions for growth of protozoa. The same conditions were used as for experiments on protozoal survival except that neomycin was omitted from the incubation medium. At the end of an experiment in which protozoa had been incubated with a $\left[{ }^{14} \mathrm{C}\right]$ labelled compound, the culture was centrifuged and the protozoa washed twice at $300 \mathrm{~g}$ for $30 \mathrm{sec}$. in salt solution B.

Breakage of protozoa. The protozoa suspended in $2.5 \mathrm{ml}$. salt solution B (for metabolic experiments) or water (for fractionation of labelled protozoa) were broken by immersion of the tube to the depth of the liquid in the tube in a $80 \mathrm{kc} / \mathrm{sec} .40 \mathrm{~W}$. ultrasonic cleaning bath (KG 80/1, manufactured by Kerry's of Chester Hall Lane, Basildon, Essex) for $15 \mathrm{sec}$. Unless the crude homogenate was required, the whole was then centrifuged at $7000 \mathrm{~g}$ for $20 \mathrm{~min}$. The supernatant fluid from this centrifugation is hereafter referred to as the 'broken-cell supernatant fluid' and the pellet after washing once in water as the 'broken-cell pellet'. This latter fraction contained all the viable bacteria and the polysaccharide granules in the homogenate.

Estimation of ${ }^{14} \mathrm{C}$ and ${ }^{32} \mathrm{P} .{ }^{14} \mathrm{C}$ or ${ }^{32} \mathrm{P}$ in any material was estimated by pipetting a sample on to an aluminium planchet of area $4.7 \mathrm{~cm} .^{2}$ carrying a disc of lens tissue. The sample was spread by one drop of cetyltrimethylammonium bromide solution $(5 \mathrm{mg} . / \mathrm{ml}$.) and fixed by one drop of polyvinyl alcohol $(2 \mathrm{mg} . / \mathrm{ml}$.). The disc was dried at $40^{\circ}$ and the radioactivity estimated by means of an automatic flow counter (NuclearChicago Corp.) with an efficiency for ${ }^{14} \mathrm{C}$ of about $20 \%$. Over 1000 counts at a rate greater than twice background (usually greater than five times) were recorded for all fractions. Determinations were made with less than $0.5 \mathrm{mg}$. material $/ \mathrm{cm} .^{2}$ of disc. The amount of sugar incorporated by protozoa or into the fraction sampled was calculated from the known specific activity of the sugar added initially. To determine the relative ${ }^{14} \mathrm{C}$ or ${ }^{32} \mathrm{P}$ contents of spots on a chromatogram a thin mica end-window GM tube was placed directly on the spot, the position of which had been determined by radioautography.

Fractionation of protozoa. The two fractions obtained by sonic treatment and centrifugation of a protozoal suspension were further fractionated by a method based on that of Roberts et al. (1955). The fraction was treated with $5 \%$ trichloroacetic acid (TCA) and allowed to stand at $4^{\circ}$ for $30 \mathrm{~min}$. The precipitate was centrifuged down and washed once in $5 \%$ TCA. The supernatant fluid and the washing formed the 'cold TCA-soluble fraction'. This fraction of the broken-cell supernatant fluid is hereafter referred to as the protozoal 'pool'. The precipitate was then extracted with $75 \%$ (v/v) ethanol in water at $40^{\circ}$ for $30 \mathrm{~min}$. The residue was centrifuged down and the supernatant fluid formed the ethanol-soluble fraction. The precipitate was then extracted with $75 \%$ ethanol +ether (I + I by vol.) at $40^{\circ}$ for $15 \mathrm{~min}$. The residue was centrifuged down and the supernatant fluid formed the ethanol+ether soluble fraction. The precipitate was then extracted twice with $5 \%$ TCA at $100^{\circ}$ for $30 \mathrm{~min}$. The supernatant fluids formed 'the hot TCA-soluble fraction'. The residue after washing once with acidified ethanol formed the 'residual protein fraction'. The TCA was removed from fractions by washing three times with ether before plating out for the estimation of ${ }^{14} \mathrm{C}$. The ethanol and ethanol+ether soluble fractions were further 
fractionated by the addition of equal quantities of water and ether and the two layers so obtained separated. The aqueous layers after washing once with ether were combined and formed the 'ethanol-soluble protein' fraction. The ether layers plus the washing were combined to form the 'lipid fraction'.

Paper chromatography. The following solvents were used: (A) sec-butanol + formic acid + water $(70+10+20$, by vol.); (B) $n$-propanol + ethyl acetate + water $(24+13+7$, by vol.); (C) tert-butanol + ammonia (sp.gr. $=0.880)+$ water $(60+30+10$, by vol.) on paper impregnated with $0.0 \mathrm{I} \mathrm{M}-\mathrm{Na}_{2} \mathrm{~B}_{4} \mathrm{O}_{7}$ (Agarwal, Sanwal \& Krishnan, 1963); (D) phenol+ammonia (sp.gr. $=0.880)+$ water $(80 \mathrm{~g} .+0.3 \mathrm{ml} .+20 \mathrm{ml}$.); (E) methanol+ammonia (sp.gr. $=0.9015)+$ water $(60+10+30$, by vol.; Bandurski \& Axelrod, 195I); (F) n-butanol + cyclohexane + propylene glycol + water + ammonia (sp.gr. $=0 \cdot 880)+$ morpholine $(30+30+10+3 \cdot 5+0 \cdot 7+0 \cdot 07$, by vol.; Guillaume \& Osteux, I955); (G) $n$-butanol saturated with $\mathrm{I} \cdot 5 \mathrm{~N}-\mathrm{NH}_{4} \mathrm{OH}$; $(\mathrm{H})$ isopropanol+water $(80+20$, by vol.; Smith, I960).

Identification of $\left[{ }^{14} \mathrm{C}\right]$ glucose in protozoal fractions. The material was first chromatographed in solvent B which separated hexoses from pentoses, disaccharides and phosphate esters, and the position of radioactive spots determined by radioautography. The spot that ran next to marker glucose was eluted and identified in the following way. It was chromatographed against markers in solvents $\mathrm{A}$ to $\mathrm{H}$ and shown to be glucose. The material was also chromatographed in solvent B before and after treatment with glucose oxidase. As a result of enzyme action the original spot disappeared and was replaced by another which ran with the same $R_{F}$ as that produced from pure $\left[{ }^{14} \mathrm{C}\right]$ glucose under the same conditions. When sufficient material was present the spots on the paper after chromatographic separation were shown to give the characteristic hexose reaction when treated with aniline oxalate reagent (Horrocks \& Manning, 1949). When insufficient material was present the identity of the glucose was confirmed by the 'fingerprint' technique of Roberts et al. (1955). For this method the unknown $\left[{ }^{4} \mathrm{C}\right]$ compound was mixed with a relatively large amount of the $\left[{ }^{12} \mathrm{C}\right]-$ form of the compound with which it had been identified and the whole chromatographed. The ${ }^{14} \mathrm{C}$ spot was then detected by radioautography and the carrier compound by the aniline oxalate reagent. When the tracer and carrier compound are the same, then the pattern of the radioautogram must agree in every detail with the pattern produced by the chemical spray.

Identification of other $\left[{ }^{14} \mathrm{C}\right]$ sugars in the protozoal 'pool'. The method adopted was similar to that for $\left[{ }^{14} \mathrm{C}\right]$ glucose with the exception that the glucose oxidase treatment had no effect on the chromatographic behaviour of the $\left[{ }^{4} \mathrm{C}\right] \mathrm{material}$.

Identification and estimation of ${ }^{14} C$ in volatile fatty acids. The volatile acids produced during the metabolism of $\left[{ }^{4} \mathrm{C}\right]$ carbohydrates were removed from the medium by steam distillation and then the distillate was neutralized, evaporated to dryness in vacuo and the residue chromatographed in solvent $F$, which separated formic, acetic, propionic and butyric acids. Immediately after removal from the tank and while the chromatogram was still wet, it was sprayed with $0.0 \mathrm{I} \mathrm{M}-\mathrm{NaOH}$ to fix the acids on the paper. To determine the position of the various fatty acids, marker mixtures of formic, acetic, propionic, $n$-butyric and $n$-valeric acids containing each acid in turn labelled with ${ }^{14} \mathrm{C}$ were chromatographed on the same paper. The relative $\left[{ }^{14} \mathrm{C}\right]$ content of the various spots was determined by placing a thin mica end-window GM tube directly on the paper. 
Protozoal counts. The number of protozoa was estimated by the method of Coleman (1958). Only those protozoa which showed no signs of disintegration were counted.

Phosphorylase assay. The incubation medium consisted of $\mathrm{I} \cdot 5 \mathrm{ml}$. O.I M- $\beta \beta^{\prime}$-dimethylglutarate buffer ( $\mathrm{pH} \mathrm{6.4)}, 0.5$ to $\mathrm{I} \cdot 0 \mathrm{ml}$. water (chosen so that the final volume was $3.0 \mathrm{ml}$.), $0 . \mathrm{I} \mathrm{ml} .{ }^{32} \mathrm{P}$-inorganic phosphate, $0 . \mathrm{I}$ to $0.6 \mathrm{ml}$. $0.00 \mathrm{I}$ to $0 . \mathrm{I} \mathrm{M}$-phosphate buffer (pH 6.4), $0.2 \mathrm{ml}$. carbohydrate solution (usually $2 \%$ soluble starch for experiments on glucan phosphorylase) and $0.1 \mathrm{ml}$. I \% L-cysteine hydrochloride (neutralized). Gas mixture $95 \%(\mathrm{v} / \mathrm{v}) \mathrm{N}_{2}+5 \%$ (v/v) $\mathrm{CO}_{2}$ was bubbled through the medium for $2 \mathrm{~min}$. immediately after the addition of the cysteine and before the addition of $0.2 \mathrm{ml}$. broken protozoal preparation. The tubes were then gassed for a further Io sec. before sealing with a rubber bung and incubation at $39^{\circ}$ usually for $30 \mathrm{~min}$. At the end of the incubation $0.2 \mathrm{ml} .0 .5 \mathrm{M}-\mathrm{NaF}$ and $0.2 \mathrm{ml}$. 0.2 M-phosphate buffer $(\mathrm{pH} \mathrm{6.4})$ were added and the whole mixed. Then $0.6 \mathrm{ml}$. magnesia mixture (Leloir \& Cardini, 1957) was added, the contents of the tube mixed and the whole allowed to stand at $4^{\circ}$ for $\mathrm{I} \mathrm{hr}$. At the end of this period the precipitate was centrifuged down and $0.2 \mathrm{ml}$. of the supernatant fluid plated out for the estimation of ${ }^{32} \mathrm{P}$.

Glucose estimations. Glucose was estimated by the method of Huggett \& Nixon (1957) by using a carbohydrase-free preparation of glucose oxidase (Type V of Sigma Chemical Co., I2 Lettice Street, London, S.W. 6).

Maltose estimation. Maltose was estimated as glucose after hydrolysis in $\mathrm{N}^{-} \mathrm{H}_{2} \mathrm{SO}_{4}$ for $30 \mathrm{~min}$. at $100^{\circ}$, followed by neutralization with $\mathrm{NaOH}$. The results were corrected for the amount of free glucose present before hydrolysis.

Reducing sugar estimations. Reducing sugars were estimated by the ferricyanide method of Park \& Johnson (1949).

Hexokinase assay. The incubation medium contained $\mathrm{I} \cdot 0 \mathrm{ml}$. salt solution $\mathrm{B}$, $0.6 \mathrm{ml}$. $0.00 \mathrm{I}$ to $0 . \mathrm{I} \mathrm{M}\left[\mathrm{U}-{ }^{14} \mathrm{C}\right]$ glucose or water, $0 . \mathrm{I} \mathrm{ml}$. $0.1 \mathrm{M}$-adenosine triphosphate (ATP) and $0.2 \mathrm{ml}$. broken protozoal supernatant fluid. The reaction was usually allowed to continue for $30 \mathrm{~min}$. at $39^{\circ}$ and was then stopped by heating at $100^{\circ}$ for $5 \mathrm{~min}$. Two $\mathrm{ml}$. of a suspension of Dowex 2 [acetate] was added and the whole shaken for $15 \mathrm{~min}$. to remove the $\left[{ }^{4} \mathrm{C}\right]$ hexose phosphates. The resin was then washed twice with water and the phosphates removed by treatment with $3 \mathrm{ml} . \mathrm{N}-\mathrm{HCl}$ a sample of which was plated out for the estimation of ${ }^{14} \mathrm{C}$. The ${ }^{14} \mathrm{C}$ in the eluate was used as a measure of enzyme activity.

Phosphoglucomutase assay. The reaction mixture contained $\mathrm{I} \cdot 0 \mathrm{ml}$. $0 \cdot \mathrm{I} \mathrm{M}-\beta \beta^{\prime}-$ dimethylglutarate buffer ( $\mathrm{pH} \mathrm{6.4),0.6} \mathrm{ml.} \mathrm{0.0} \mathrm{I} \mathrm{to} 0 . \mathrm{I}$ M-glucose-I-phosphate or water and $0.2 \mathrm{ml}$. broken protozoal supernatant fluid. Tubes were incubated at $39^{\circ}$ for $30 \mathrm{~min}$. and the reaction stopped by heating at $100^{\circ}$ for $5 \mathrm{~min}$. The precipitate was centrifuged down and $0.1 \mathrm{ml}$. of the supernatant fluid used for the estimation of reducing sugars, with glucose-6-phosphate as a standard. To correct for the reducing materials present in the reagents initially, reducing sugar estimations were done at each glucose-I-phosphate concentration before and after incubation.

Maltase assay. The reaction mixture contained $\mathrm{I} \cdot 0 \mathrm{ml}$. salt solution $\mathrm{B}, 0.6 \mathrm{ml}$. 0.01 to $0.1 \mathrm{M}$-maltose or water and $0.2 \mathrm{ml}$. broken protozoal supernatant fluid. Tubes were incubated at $39^{\circ}$ for $30 \mathrm{~min}$. and the reaction stopped by heating at $100^{\circ}$ for $5 \mathrm{~min}$. The precipitate was centrifuged down and $0.1 \mathrm{ml}$. of the supernatant fluid used for the estimation of glucose. To correct for the glucose present in the maltose, glucose estimations were carried out at each maltose concentration before and after incubation. 
Preparation of $\left[{ }^{4} \mathrm{C}\right]$ labelled starch grains. The method was based on the observation of Oxford (1951) that rumen holotrich protozoa rapidly convert glucose into an intracellular glucosan. A sample ( $500 \mathrm{ml}$.) of crude rumen contents from a Clun Forest sheep fed on hay and oats was strained through muslin and allowed to stand in a separating funnel at $39^{\circ}$ for $45 \mathrm{~min}$. The sediment, which consisted principally of holotrich protozoa, was run off into an $8 \times \mathrm{I}$ in. $(20 \times 2.5 \mathrm{~cm}$.) test tube and washed three times with salt solution $\mathrm{B}$ by sedimentation under gravity. The washed protozoa were inoculated into $5 \mathrm{ml}$. salt solution B (from which the sodium propionate was omitted) containing [U-14 C]glucose $\left(0.5 \mathrm{mg}\right.$. and $6 \mu \mathrm{c} / \mathrm{ml}$.) and $0.2 \mathrm{ml}$. saturated $\mathrm{NaHCO}_{3}$ and through which $\mathrm{CO}_{2}$ had been bubbled for $2 \mathrm{~min}$. After inoculation the tubes were gassed with $\mathrm{CO}_{2}$ for Io sec., sealed with a rubber bung and incubated horizontally for $2 \mathrm{hr}$ at $39^{\circ}$. The protozoa were then harvested, washed four times in salt solution B and broken in a Potter homogenizer (Potter \& Elvehjem, 1936). The homogenate was centrifuged at $1200 \mathrm{~g}$ for $15 \mathrm{~min}$. and the pellet of starch grains washed twice in water under the same conditions. Approximately $10 \%$ of the ${ }^{14} \mathrm{C}$ present in the glucose initially was converted into $\left[{ }^{14} \mathrm{C}\right]$ starch. On fractionation of these grains (see Methods) over $96 \%$ of the ${ }^{14} \mathrm{C}$ was solubilized on treatment with $5 \%$ TCA at $100^{\circ}$ for $20 \mathrm{~min}$., and on further hydrolysis of this extract in $\mathrm{N}-\mathrm{HCl}$ for $\mathrm{I} \mathrm{hr}$ at $100^{\circ}$ glucose was found to be the only ${ }^{14} \mathrm{C}$-labelled monosaccharide present; only $0.4 \%$ of the ${ }^{14} \mathrm{C}$ was present in the protein fraction. These results indicated that the preparation contained $\left[{ }^{14} \mathrm{C}\right]$ starch contaminated with very little protein.

Chemicals. $\left[{ }^{14} \mathrm{C}\right]$ compounds were supplied by the Radiochemical Centre, Amersham, Buckinghamshire. The specific activities of the compounds, as supplied, were in $\mu \mathrm{C} / \mathrm{mg}$., [I- $\left.{ }^{14} \mathrm{C}\right]-\mathrm{D}$-galactose, $20 \cdot 8$; [U-14 $\left.\mathrm{C}\right]-\mathrm{D}$-glucose, 16.2; [U-1 $\left.{ }^{14} \mathrm{C}\right]-\mathrm{D}-$ maltose, 13.5 ; [I-14 C]-D-ribose, 54.9; [U-14 C]soluble starch, 26; [U-14 C]sucrose, 3.5. All sugars were usually used within 6 months of receipt and were always checked for purity by chromatography in solvents $\mathbf{A}$ and $\mathbf{B}$.

\section{RESULTS}

\section{Metabolism of intact starch grains}

Entodinium caudatum suspensions were incubated with the ${ }^{14} \mathrm{C}$-labelled starch grains (see Methods) for $48 \mathrm{hr}$ either under standard conditions in the presence of penicillin + neomycin when there was no bacterial growth and the number of protozoa decreased by $26 \%$ or under conditions which allowed both protozoal and bacterial growth (Coleman, I960 $\mathrm{b}$ ) when the number of protozoa increased by $45 \%$. Table I shows that under both conditions there was no evidence for any synthesis of protein from carbohydrate. Over $80 \%$ of the protozoal ${ }^{14} \mathrm{C}$ was found in the hot TCA soluble fraction of the broken-cell pellet: ${ }^{14} \mathrm{C}$ from the original starch grains and any other granular polysaccharide would be liberated in this fraction. With non-multiplying protozoa over $50 \%$ of the ${ }^{14} \mathrm{C}$ from the $\left[{ }^{14} \mathrm{C}\right]$ starch was liberated into the medium as soluble non-volatile material which was identified as glucose $(65 \%)$ and maltose $(35 \%)$. The volatile compounds were acetate $(35 \%)$ and butyrate $(65 \%)$; no propionate was detected. In an attempt to demonstrate the presence of $\left[{ }^{14} \mathrm{C}\right]$ lactate, the untreated supernatant fluid was chromatographed in solvent $\mathbf{A}$, which separated lactate from glucose and maltose but less than $\mathrm{I} \%$ of the total ${ }^{14} \mathrm{C}$ could have been present as lactate. The remainder of the ${ }^{14} \mathrm{C}$ in the presence of non-multiplying protozoa and 
most of the ${ }^{14} \mathrm{C}$ in the presence of multiplying protozoa was not retained on planchetes in the presence of acid or alkali and was presumed to be $\mathrm{CO}_{2}$.

\section{Effect of metabolism of starch on sugar concentrations in the protozoal pool and the medium}

On incubation of Entodinium caudatum in the absence of added carbohydrate or of antibiotics there was a steady decline in the amount of glucose and maltose in the pool accompanied by a corresponding increase in the amount in the medium such that the total amount of free + bound glucose remained almost constant over the first $90 \mathrm{~min}$.

\section{Table I. The metabolism of ${ }^{14} C$-starch grains by Entodinium caudatum}

Protozoa were incubated anaerobically for $48 \mathrm{hr}$ in $10 \mathrm{ml}$. medium containing $10 \%(\mathrm{v} / \mathrm{v})$ autoclaved rumen fluid (PARF, Coleman, 1964a), 1000 units penicillin $\mathrm{G} / \mathrm{ml}$. and $0.14 \mu \mathrm{C}$ ${ }^{14} \mathrm{C}$-starch grains from holotrich protozoa $/ \mathrm{ml}$. in the presence or absence of $400 \mu \mathrm{g}$. neomycin sulphate/ml. With neomycin the number of protozoa decreased by $26 \%$ and without it the number increased by $45 \%$. At the end of the experiment the washed protozoa were broken by ultrasonic treatment and the supernatant fluid and pellet fractions separated by centrifugation.

\begin{tabular}{|c|c|c|c|c|c|}
\hline & \multicolumn{5}{|c|}{ Radioactivity (percentage of ${ }^{14} \mathrm{C}$ added initially) } \\
\hline & $\begin{array}{c}\text { No } \\
\text { protozoa }\end{array}$ & \multicolumn{2}{|c|}{$\begin{array}{l}\text { Multiplying protozoa } \\
\text { (- neomycin) }\end{array}$} & \multicolumn{2}{|c|}{$\begin{array}{l}\text { Non-multiplying protozoa } \\
\text { (+ neomycin) }\end{array}$} \\
\hline $\begin{array}{l}\text { Non-volatile soluble material } \\
\text { in medium }\end{array}$ & $1 \cdot 8$ & \multicolumn{2}{|c|}{$9 \cdot 9$} & \multicolumn{2}{|c|}{$55 \cdot 9$} \\
\hline \multirow[t]{2}{*}{ Volatile acid } & 0 & \multicolumn{2}{|c|}{$3 \cdot 9$} & \multicolumn{2}{|c|}{$19 \cdot 0$} \\
\hline & $\begin{array}{l}\text { Initial } \\
\text { starch }\end{array}$ & $\begin{array}{l}\text { Supernatant } \\
\text { fluid }\end{array}$ & Pellet & $\begin{array}{l}\text { Supernatant } \\
\text { fluid }\end{array}$ & Pellet \\
\hline Cold TCA-soluble & $2 \cdot 8$ & 0.45 & $0 \cdot 14$ & 0.33 & $0.1 \mathrm{I}$ \\
\hline Lipid & 0.6 & 0.01 & 0.06 & 0.01 & 0.04 \\
\hline Hot TCA-soluble & $94 \cdot 4$ & 0.06 & $4 \cdot 4$ & 0.05 & $7 \cdot 4$ \\
\hline Protein & 0.4 & $0 \cdot 10$ & $0 \cdot 30$ & 0.03 & 0.15 \\
\hline
\end{tabular}

Table 2. The effect of the metabolism of starch grains on the concentration of maltose and glucose in the medium and pool of Entodinium caudatum

$1.6 \times 10^{6}$ protozoa were incubated anaerobically in $\mathrm{I} \cdot 2 \mathrm{ml}$. salt solution $\mathrm{B}$ in the presence or absence of $1.5 \%$ suspension of rice starch. At the times shown the protozoa were centrifuged down, washed twice in salt solution $B$, broken by ultrasonic treatment and the supernatant fluid separated from the pellet by centrifugation. The pool was the cold TCA soluble fraction of the protozoal supernatant fluid. The concentration of maltose and glucose in the pool and the incubation medium were determined as described in Methods. All results are expressed in $\mu$ moles.

\begin{tabular}{|c|c|c|c|c|c|c|c|c|}
\hline \multirow{3}{*}{$\begin{array}{l}\text { Time } \\
\text { (min.) }\end{array}$} & \multicolumn{4}{|c|}{ Protozoal pool } & \multicolumn{4}{|c|}{ Medium } \\
\hline & \multicolumn{2}{|c|}{ - starch } & \multicolumn{2}{|c|}{ + starch } & \multicolumn{2}{|c|}{ - starch } & \multicolumn{2}{|c|}{ + starch } \\
\hline & Maltose & Glucose & Maltose & Glucose & Maltose & Glucose & Maltose & Glucose \\
\hline 0 & 0.368 & 0.412 & 0.378 & 0.425 & 0.040 & 0.100 & 0.176 & 0.100 \\
\hline 5 & 0.346 & 0.388 & 0.453 & 0.578 & 0.044 & 0.112 & 0.284 & 0.140 \\
\hline 15 & 0.382 & 0.418 & 0.408 & 0.480 & 0.056 & 0.100 & 0.306 & 0.160 \\
\hline 30 & 0.314 & 0.380 & 0.404 & 0.480 & 0.104 & 0.112 & 0.464 & 0.220 \\
\hline 90 & 0.312 & 0.328 & 0.422 & 0.348 & 0.080 & 0.132 & 0.746 & 0.408 \\
\hline 240 & 0.248 & 0.260 & 0.262 & 0.248 & 0.236 & 0.148 & $1 \cdot 50$ & 0.584 \\
\hline
\end{tabular}


In the presence of added rice starch (additional to that already present in the protozoa on harvesting) there was an initial (in first $5 \mathrm{~min}$.) 20 to $25 \%$ increase in the amount of glucose and maltose in the pool but thereafter the amount of each declined as in the absence of added starch (Table 2). The amount of glucose in the pool initially was always greater, on a molar basis, than the amount of maltose. In contrast in the presence of added starch there was a large increase in the amount of maltose liberated into the medium and a smaller increase in the amount of glucose. These results indicate that the sugars were probably not liberated into the medium by an 'overflow' from the pool but may have been liberated directly without passage through the pool.

In freshly harvested protozoa the quantity of free glucose and maltose present in ${ }_{10} 0^{6}$ protozoa was 0.26 and $0.23 \mu$ moles, respectively. Since the volume of each protozoon was $4.7 \times 10^{4} \mu^{3}$ (Coleman, 1967a) the total volume of $10^{6}$ ciliates was $4.7 \times 10^{10} \mu^{3}$ or $0.047 \mathrm{ml}$. The minimum concentration of glucose and maltose was therefore 5.5 and $4.9 \mu \mathrm{moles} / \mathrm{ml}$, respectively. Since $26 \%$ of a packed protozoal pellet was solid material (Coleman, 1967a) and since it is considered likely that these sugars were not present in the $37 \%$ of the cell (see below) in and out of which low molecular weight compounds could pass readily, it is probable that these sugars were present in $37 \%$ of the cell volume. If this is correct then the concentration of glucose and maltose was 14.8 and $13.2 \mathrm{~mm}$, respectively.

\section{Table 3. Distribution of ${ }^{14} \mathrm{C}$ in Entodinium caudatum after the incorporation of $\left[U-{ }^{14} C\right]$ glucose}

Protozoa $\left(7.6 \times 10^{5}\right)$ were incubated anaerobically for $5 \mathrm{hr}$ in salt solution $\mathrm{B}$ containing 1000 units penicillin $+400 \mu \mathrm{g}$. neomycin sulphate $/ \mathrm{ml}$. in the presence of $0.8 \mathrm{~mm}$ [U-14 C] glucose $\left(670,000\right.$ counts $/ \mathrm{min}$.) or $110 \mathrm{mM}-\left[\mathrm{U}-{ }^{14} \mathrm{C}\right] \mathrm{glucose}(670,000 \mathrm{counts} / \mathrm{min}$.). After incubation the washed protozoa were broken by ultrasonic treatment and the supernatant fiuid and pellet fractions separated by centrifugation. These were further fractionated as described in Methods.

Initial glucose concentration

Cold TCA-soluble fraction

Ethanol-soluble protein

Lipid

Hot TCA-soluble fraction

Residual protein
Radioactivity (counts/min.)

\begin{tabular}{|c|c|c|c|}
\hline \multicolumn{2}{|c|}{$\begin{array}{l}\text { Broken-cell } \\
\text { supernatant fluid }\end{array}$} & \multicolumn{2}{|c|}{$\begin{array}{c}\text { Broken-cell } \\
\text { pellet }\end{array}$} \\
\hline $0.8 \mathrm{~mm}$ & $110 \mathrm{mM}$ & $0.8 \mathrm{~mm}$ & I IO $\mathrm{mM}$ \\
\hline I380 & 720 & I I IO & 540 \\
\hline 15 & 5 & 30 & 0 \\
\hline 35 & 20 & 30 & 15 \\
\hline 70 & 30 & 2660 & I I IO \\
\hline 50 & 20 & 60 & 15 \\
\hline
\end{tabular}

\section{Metabolism of glucose}

Washed suspensions of Entodinium caudatum incubated anaerobically in the presence of penicillin + neomycin for $5 \mathrm{hr}$ incorporated ${ }^{14} \mathrm{C}$ from $0.8 \mathrm{mM}$ and $0 . \mathrm{II} \mathrm{M}$ [U-14 C]glucose. Table 3 shows that the distribution of ${ }^{14} \mathrm{C}$ was similar under both conditions and that 26 to $29 \%$ was present in the cell pool and 45 to $50 \%$ in the hot TCA soluble fraction of the broken cell pellet: after further hydrolysis in $\mathrm{N}-\mathrm{HCl}$ for $\mathrm{I} \mathrm{hr}$ at $100^{\circ}$ the material in the latter fraction was identified as $\left[{ }^{14} \mathrm{C}\right]$ glucose. This suggested that in the intact protozoa the ${ }^{14} \mathrm{C}$ was present as a glucose polysaccharide. Less than $3 \%$ of the total protozoal ${ }^{14} \mathrm{C}$ was present in the protein fractions. $4 \%$ of the glucose-carbon present initially was converted into volatile fatty acids as acetate 
$(80 \%)$ and butyrate $(20 \%)$. The different proportions of acetate and butyrate produced during the metabolism of glucose and starch could be the result of the differing action of intracellular bacteria on the hydrolysis products of starch digested in the cytoplasm and on glucose taken up from the medium.

Distribution of ${ }^{14} C$ in the hot $T C A$ soluble fraction of the broken cell pellet. In contrast to the results obtained with $\left[{ }^{14} \mathrm{C}\right]$ glycine or $\left[{ }^{14} \mathrm{C}\right]$ bicarbonate (Coleman, $1964 a$ ) when breakage of the protozoa abolished incorporation of ${ }^{14} \mathrm{C}$ into the pellet, the incorporation of ${ }^{14} \mathrm{C}$ from $\left[{ }^{14} \mathrm{C}\right]$ glucose into the pellet was increased by up to $60 \%$ on protozoal breakage. This suggested that the incorporation under these conditions was into bacteria and that in the intact protozoon $\left[{ }^{14} \mathrm{C}\right]$ glucose could be incorporated into intracellular bacteria and possibly protozoal polysaccharide granules, both of which would be found in the broken-cell pellet after cell breakage and centrifugation.

Incorporation of ${ }^{14} \mathrm{C}$ from $\left[{ }^{14} \mathrm{C}\right]$ glucose by bacteria isolated from protozoa. White (I966) found forty viable bacteria inside each ciliate and showed that $90 \%$ of these were one or the other of two species of Gram-negative bacilli. These have been shown subsequently to be Klebsiella aerogenes (Bacterium 3I used by Coleman 1964 $b, 1967 b$ ) and Proteus mirabilis (R. W. White, personal communication). Cultures of these bacteria were grown anaerobically on a yeast-extract + tryptose + glucose + salts medium (Coleman, 1964b) and washed suspensions prepared by washing the bacteria twice on the centrifuge in salt solution B. These suspensions were incubated anaerobically for $20 \mathrm{~min}$. at $39^{\circ}$ with $0.5 \times 10^{-3}$ to $80 \mathrm{mM}-\left[\mathrm{U}-{ }^{14} \mathrm{C}\right] \mathrm{glucose}$ of known specific activity and the incorporation of ${ }^{14} \mathrm{C}$ into washed bacteria measured. Figure $\mathrm{I}$ is a reciprocal plot of ${ }^{14} \mathrm{C}$ incorporated against substrate concentration and shows that both bacterial species incorporated ${ }^{14} \mathrm{C}$ but that $K$. aerogenes was over four times as active as $P$. mirabilis. Both curves showed a very marked discontinuity at Io to $20 \mathrm{mM}$. On incubation of $K$. aerogenes anaerobically in the presence of glucose concentrations in excess of $0.001 \mathrm{M}$, a fluffy layer of what was presumed to be a glucose polymer was found associated with the bacteria on centrifugation. On fractionation of all the sedimented material over $90 \%$ of the glucose-carbon that had been incorporated was released by treatment with hot $5 \% \mathrm{TCA}$ and after further hydrolysis in $\mathrm{N}-\mathrm{HCl}$ was found to be glucose. It was essential in these experiments to use short incubation times because after I hr, especially at high glucose concentrations, so much 'fluffy' material was formed that it was impossible to remove the supernatant fluid after centrifugation without removing some.

Determination of incorporation of ${ }^{14} \mathrm{C}$ into protozoal polysaccharide and intracellular bacteria. The method used to distinguish between incorporation into protozoal polysaccharide and bacteria was based on the observation that, after centrifugation of the protozoal broken-cell pellet through sucrose, much of the starch but few of the bacteria were present in the pellet as observed microscopically. To obtain a quantitative result it was necessary to assume that on incubation of broken protozoa with $\left[{ }^{4} \mathrm{C}\right]$ glucose ${ }^{14} \mathrm{C}$ was incorporated only into bacteria. The washed pellet from such an incubation was resuspended in $2 \mathrm{ml}$. water and samples layered on top of $2 \mathrm{ml}$. quantities of sucrose of differing molarities and centrifuged at $1900 \mathrm{~g}$ for $10 \mathrm{~min}$. in a bucket-head centrifuge. The supernatant fluids were removed and the pellets, after washing once in water, plated out for the estimation of ${ }^{14} \mathrm{C}$. They contained $73,20,2.5$ and $\mathrm{I} \cdot 7 \%$ of the initial ${ }^{14} \mathrm{C}$ after centrifugation through $\mathrm{I} \cdot 0, \mathrm{I} \cdot 5,2.0$ and $2.5 \mathrm{M}$-sucrose, respectively. From an examination of this result it was decided to use $2 \mathrm{M}$-sucrose and by 
direct microscopical examination $30 \%$ of the original number of protozoal polysaccharide granules were found in the pellet after centrifugation through sucrose. It was therefore possible to obtain an estimate of the amount of ${ }^{14} \mathrm{C}$ incorporated into the protozoal polysaccharide granules by centrifugation of the broken-cell pellet through $2 \mathrm{M}$-sucrose and multiplying the amount of ${ }^{14} \mathrm{C}$ in this second pellet by 3.3 . For the purposes of these calculations the $2.5 \%$ of the bacterial ${ }^{14} \mathrm{C}$ that centrifuged through $2 \mathrm{M}$-sucrose was ignored. The amount of ${ }^{14} \mathrm{C}$ in the intracellular bacteria was the difference between the total ${ }^{14} \mathrm{C}$ in the broken-cell pellet and the ${ }^{14} \mathrm{C}$ in the protozoal polysaccharide measured as described above.

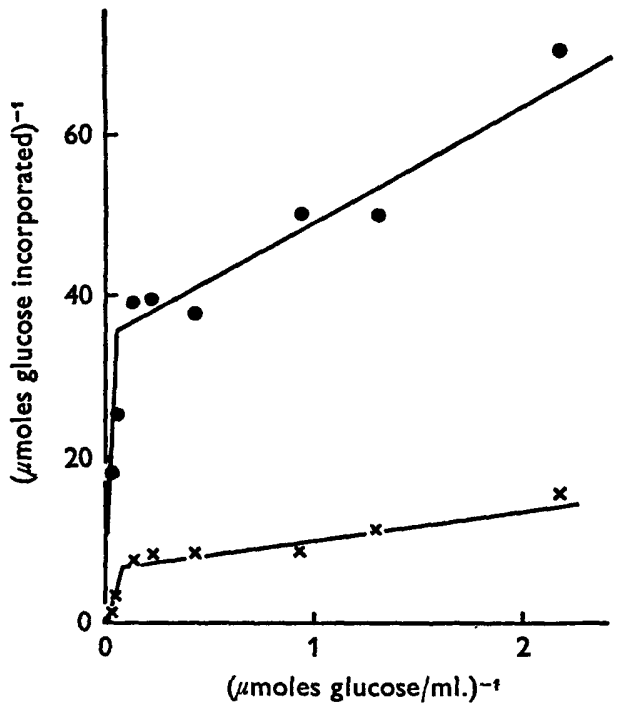

Fig. I

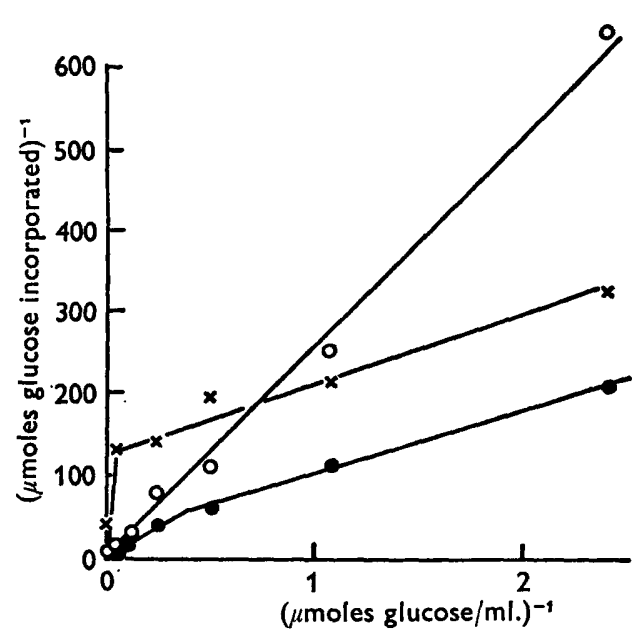

Fig. 2

Fig. I. Effect of glucose concentration on the incorporation of ${ }^{14} \mathrm{C}$ from $\left[\mathrm{U}-{ }^{14} \mathrm{C}\right] \mathrm{glucose}$ by washed suspension of Proteus mirabilis (-) and Klebsiella aerogenes $(x-\infty)$ incubated anaerobically in salt solution B. Duration of experiment 20 min. Results expressed per $10^{\circ}$ bacteria.

Fig. 2. Effect of glucose concentration on the incorporation of ${ }^{14} \mathrm{C}$ from $\left[\mathrm{U}-{ }^{14} \mathrm{C}\right] \mathrm{glucose}$ by Entodinium caudatum. After $45 \mathrm{~min}$. the washed protozoa were treated ultrasonically and separated into supernatant fluid and pellet fractions by centrifugation. The cold TCAsoluble material from the broken-cell supernatant fluid formed the pool (-O). The pellet fraction was further fractionated by centrifugation through $2 \mathrm{M}$-sucrose to give a protozoal polysaccharide $(\mathrm{O}-\mathrm{O})$ and a bacterial $(x-x)$ fraction.

Figure 2 is a reciprocal plot of the effect of glucose concentration on the incorporation of ${ }^{14} \mathrm{C}$ from $\left[{ }^{14} \mathrm{C}\right]$ glucose and shows that there was a discontinuity in the curves for incorporation into the pool and the bacteria but not for incorporation into protozoal polysaccharide. The break in the curve for uptake into the bacteria occurred at $20 \mathrm{mM}$, which was at the same concentration as was found with pure cultures of the two predominant bacterial species and may therefore not be associated with any protozoal process. The discontinuity in the curve for incorporation into the pool (at $2.5 \mathrm{~mm}$ ) and the fact that the left-hand part passed through the origin suggested there may be an 'active' (predominant at low glucose concentrations) and a passive (predominant at 
high glucose concentrations) uptake process as was found for amino acids (Coleman, 1967a).

In an attempt to obtain further evidence for the existence of incorporation into both subfractions of the broken-cell pellet, the effect of penicillin (I000 units $/ \mathrm{ml}$.) + neomycin $\left(400 \mu \mathrm{g}\right.$. $/ \mathrm{ml}$.) on incorporation of ${ }^{14} \mathrm{C}$ from $\left[{ }^{4} \mathrm{C}\right] \mathrm{glucose}$ was investigated, since these antibiotics are known to kill the bacteria associated with the protozoa (Coleman, 1962). Unfortunately incubation of the protozoa with these antibiotics for $16 \mathrm{hr}$ before incubation with $\left[{ }^{14} \mathrm{C}\right] \mathrm{glucose}$ decreased the incorporation of ${ }^{14} \mathrm{C}$ into intact protozoa, the broken-cell supernatant fluid and the broken-cell pellet by $84 \%$, and it was not possible to measure incorporation into the bacterial and polysaccharide fractions satisfactorily. However, it was found that, whereas breakage of freshly harvested protozoa before incubation with $\left[{ }^{14} \mathrm{C}\right]$ glucose stimulated incorporation of ${ }^{14} \mathrm{C}$ into the pellet, breakage of protozoa that had been pre-incubated with antibiotics for $16 \mathrm{hr}$ decreased incorporation of ${ }^{14} \mathrm{C}$ into the pellet by $60 \%$. This result suggests that in freshly harvested protozoa incorporation of ${ }^{14} \mathrm{C}$ was into two fractions, one of which was associated with living bacteria. It was also possible to show a selective effect of penicillin and neomycin when freshly harvested protozoa were incubated in the presence or absence of antibiotics for $4 \mathrm{hr}$. Under these conditions at low (O.I $\mathrm{mM})$ glucose concentrations, incorporation into broken-cell supernatant fluid, intracellular bacteria and protozoal polysaccharide was inhibited by 74,83 and $53 \%$ respectively in the presence of antibiotics. These results show that the incorporation into the intracellular bacteria is most sensitive to penicillin and neomycin and are generally consistent with the view that incorporation in the broken-cell pellet is into a bacterial and non-bacterial component.

Effect of other sugars and of sugar analogues. For these experiments the protozoa were incubated anaerobically with 0.4 to $67 \mathrm{mM}\left[\mathrm{U}-{ }^{14} \mathrm{C}\right]$ glucose in the presence of the inhibitor at $67 \mathrm{mM}$, and the incorporation into the protozoal pool and polysaccharide and the intracellular bacteria measured. On the basis of results obtained in experiments on the total incorporation into protozoa over 3 to $4 \mathrm{hr}$ the 'sugars' were divided into two groups. Those of group I which contained D-galactose and D-2-deoxyglucose inhibited incorporation at concentrations above and below the break (at $2 \cdot 2 \mathrm{mM}$ ) in the reciprocal plot of incorporation of ${ }^{14} \mathrm{C}$ into intact protozoa/substrate concentration. Those of group 2 (i.e. D-sorbitol, D-mannose, D-maltose, D-fructose) inhibited only at concentrations below the break; L-glucose and D-ribose had no effect at any concentration. However, when the experiments were made for only $20 \mathrm{~min}$. then group 2 compounds were not inhibitory and those of group $\mathrm{I}$ inhibited markedly at concentrations below the break, but only slightly at high concentrations. At low glucose concentrations 2-deoxyglucose inhibited incorporation of ${ }^{14} \mathrm{C}$ from $\left[{ }^{14} \mathrm{C}\right]$ glucose into all the sub-cellular fractions equally (Table 4) and the same occurred in the presence of galactose although the over-all inhibition was always greater in the presence of 2-deoxyglucose, i.e. $71 \%$ compared with $29 \%$ (mean of six experiments). However at high glucose concentrations, where the over-all inhibition by both inhibitors was much smaller, the incorporation into the protozoal polysaccharide was always affected more than the incorporation into the other two fractions. The incorporation of ${ }^{14} \mathrm{C}$ from $\left[{ }^{14} \mathrm{C}\right] g l u c o s e$ by washed broken-cell pellet after a 3 -hr incubation was decreased to $54 \%$ in the presence of galactose and to $37 \%$ in the presence of 2-deoxyglucose. However, similar experiments with washed suspensions of the Klebsiella aerogenes and Proteus 
mirabilis isolated from the protozoa showed that incorporation into both bacteria was not affected by 2-deoxyglucose but was decreased to $45 \%$ by galactose. As this difference may have been the result of the exposure of the intracellular bacteria, but not the washed suspensions, to ultrasonic treatment, the effect of such treatment of washed suspensions of the bacteria on their ability to incorporate $\left[{ }^{14} \mathrm{C}\right]$ glucose was examined. On ultrasonic treatment of suspensions of either bacterium the rate of incorporation of ${ }^{14} \mathrm{C}$ from $\left[{ }^{14} \mathrm{C}\right]$ glucose decreased progressively with time of treatment and 2-deoxyglucose became progressively more inhibitory until after $30 \mathrm{sec}$. of treatment followed by $30 \mathrm{~min}$. incubation 2-deoxyglucose decreased incorporation by $30 \%$. Under the same conditions galactose inhibited incorporation by $90 \%$. Sorbitol had no effect on the incorporation of ${ }^{14} \mathrm{C}$ from $\left[{ }^{[4} \mathrm{C}\right]$ glucose by protozoal washed brokencell pellet or by either bacterium under any conditions tested.

\title{
Table 4. The effect of galactose and 2-deoxyglucose on the incorporation of ${ }^{14} \mathrm{C}$ from $\left[{ }^{14} \mathrm{C}\right]$ glucose by Entodinium caudatum
}

\begin{abstract}
Protozoa $(650,000 / \mathrm{ml}$.) were incubated anaerobically in $1.5 \mathrm{ml}$. medium for $4 \mathrm{hr}$ in the presence of $0.3 \mathrm{mM}-\left[\mathrm{U}-{ }^{14} \mathrm{C}\right]$ glucose $\left(66,000\right.$ counts $/ \mathrm{min} . / \mathrm{ml}$.) or $67 \mathrm{mM}-\left[\mathrm{U}-{ }^{14} \mathrm{C}\right] \mathrm{glucose}$ $(66,000$ counts $/ \mathrm{min} . / \mathrm{ml}$.) and in the presence or absence of $67 \mathrm{~mm}$-D-galactose (Expt. B) or $67 \mathrm{~mm}$-2-deoxyglucose (Expt. A). At the end of the experiment the washed protozoa were broken by ultrasonic treatment and the supernatant fluid and pellet fractions separated by centrifugation. The washed pellet fraction was further fractionated by centrifugation through $2 \mathrm{M}$-sucrose, as described in the text, and the incorporation of ${ }^{14} \mathrm{C}$ into the polysaccharide and bacterial fractions determined. The "pool' was the cold TCA-soluble fraction of the broken-cell supernatant fluid. Results are expressed relative to incorporation into fraction in absence of inhibitor at given glucose concentrations $=100$.
\end{abstract}

$\begin{array}{lcccc}\begin{array}{c}\text { Glucose } \\ \text { Inhibitor }\end{array} & \text { Poncentration } & \text { Pool } & \text { Bacteria } & \begin{array}{c}\text { Poly- } \\ \text { saccharide }\end{array} \\ \begin{array}{l}\text { Expt. A } \\ \text { 2-Deoxyglucose }\end{array} & 0.3 \mathrm{mM} & 7 \cdot 7 & 7 \cdot 8 & 5 \cdot 6 \\ \text { 2-Deoxyglucose } & 67 \mathrm{mM} & 73 & 54 & 28 \\ \text { Expt. B } & & & & \\ \text { Galactose } & 0.3 \mathrm{mM} & 33 & 31 & 23 \\ \text { Galactose } & 67 \mathrm{mM} & 8 \mathrm{I} & 103 & 5 \mathrm{I}\end{array}$

Nature of products in protozoal pool. The $\left[{ }^{14} \mathrm{C}\right]$ labelled constituents of the protozoal pool after incubation with $\left[{ }^{14} \mathrm{C}\right]$ glucose were separated into up to four compounds by chromatography in solvent $\mathrm{B}$. One ${ }^{14} \mathrm{C}$-spot remained at the origin and after elution and treatment with acid phosphatase gave rise to $\left[{ }^{14} \mathrm{C}\right]$ glucose (for identification of $\left[{ }^{14} \mathrm{C}\right]$ glucose see Methods). On chromatography in solvent $\mathrm{C}$ the untreated material was resolved into a major component (over $80 \%$ ) which chromatographed next to marker glucose-6-phosphate, and a minor component which chromatographed opposite glucose-I-phosphate. On elution, this latter component was hydrolysed to $\left[{ }^{14} \mathrm{C}\right]$ glucose on treatment with $\mathrm{N}_{-} \mathrm{H}_{2} \mathrm{SO}_{4}$ at $100^{\circ}$ for $10 \mathrm{~min}$.; the former was stable under these conditions as determined by chromatography in solvent $\mathrm{B}$. Both components of the origin spot were removed from solution by treatment with Dowex 2 (acetate), showing that they were moderately strong acids. Their identity was confirmed by chromatography in solvents $A$ to $G$ next to marker compounds. The second spot in the original chromatographic separation ran opposite marker maltose. After elution some of this material was hydrolysed in $\mathrm{N}-\mathrm{HCl}$ at $100^{\circ}$ for $\mathrm{I} \mathrm{hr}$ and was converted into glucose only. The remaining material was chromatographed in solvents $\mathrm{A}$ to $\mathrm{H}$ against marker 
compounds and shown to be maltose. The third spot in the original was glucose. The fourth spot which never contained more than $10 \%$ of the total ${ }^{14} \mathrm{C}$ in the pool ran slightly faster than glucose in solvent B and was probably fructose, although this was not shown conclusively.

Effect of glucose concentration and inhibitors on incorporation into the pool. After 15-min. incubation in the presence of low $(0.4 \mathrm{mM})\left[{ }^{14} \mathrm{C}\right]$ glucose $10 \%$ of the ${ }^{14} \mathrm{C}$ in the pool was present as hexose phosphate, $36 \%$ as maltose and $54 \%$ as glucose whereas in the presence of a high ( $40 \mathrm{mM}$ ) glucose concentration the corresponding proportions were 5,20 and $75 \%$. The proportion of the ${ }^{14} \mathrm{C}$ that was present as hexose phosphate was rather variable and in some experiments was as high as $35 \%$. In the presence of $20 \mathrm{~mm}$-2-deoxyglucose at low glucose concentrations the total incorporation into the pool was decreased by $65 \%$ and the distribution of ${ }^{14} \mathrm{C}$ was similar to that at high glucose concentrations. 2-Deoxyglucose had no effect on the pattern of incorporation at high glucose concentrations.

In an attempt to prevent the 'active' uptake of glucose by the protozoa the effect of $0.67 \mathrm{~mm}$-iodoacetate was investigated. At this concentration all ciliary movement of the protozoa was abolished and they began to disintegrate after incubation for $\mathrm{I} \mathrm{hr}$; all experiments in the presence of iodoacetate were therefore done for $20 \mathrm{~min}$. only. Under these conditions incorporation into the pool was increased up to six times by the presence of iodoacetate and there was a straight-line relationship between incorporation of glucose and glucose concentration on a reciprocal plot, and this straight line passed through the origin. These findings suggested that the 'active' uptake had been abolished by iodoacetate and the passive uptake increased. Incorporation into the hexose phosphate fraction in the pool and into the broken-cell pellet fraction was abolished. The relative incorporation into the glucose and maltose in the pool were unchanged.

Since the increased passive uptake of ${ }^{14} \mathrm{C}$ from $\left[{ }^{14} \mathrm{C}\right]$ glucose may have been the result of the inhibition of some process for the 'active' removal of glucose from part of the cell, the effect of iodoacetate on the release of ${ }^{14} \mathrm{C}$ from washed protozoa which had been pre-incubated with $67 \mathrm{mM}\left[{ }^{14} \mathrm{C}\right]$ glucose for $30 \mathrm{~min}$. was investigated. It was not possible to obtain an unambiguous result because, although the addition of $0.67 \mathrm{~mm}$-iodoacetate decreased the rate of loss of ${ }^{14} \mathrm{C}$ from the pool, it stimulated the release of ${ }^{14} \mathrm{C}$ from the pellet fraction of the protozoa into the medium.

Effect of salt concentration and temperature on incorporation into the pool. A decrease of $65 \%$ in the salt concentration in the incubation medium killed the protozoa after $\mathrm{I} \mathrm{hr}$ but stimulated the incorporation of ${ }^{14} \mathrm{C}$ from $\left[{ }^{14} \mathrm{C}\right]$ glucose into the pool by $260 \%$ when the incubations were continued for $20 \mathrm{~min}$. only. There was a straight line relationship between incorporation of ${ }^{14} \mathrm{C}$ and glucose concentration on a reciprocal plot, and the line passed through the origin. There was no break in the curve as occurred at standard salt concentration. Almost all the increase in the incorporation of ${ }^{14} \mathrm{C}$ was accounted for by an increase in the amount of $\left[{ }^{14} \mathrm{C}\right] g$ lucose: this increased by $420 \%$ compared with only $55 \%$ for maltose. This result can probably be explained on the basis of a passive uptake of medium into the protozoa caused by the lowered osmotic pressure. The glucose would be carried into the protozoa with the other medium constituents and be trapped there when the protozoa were washed in salt solution of the standard concentration.

Lowering the temperature from $40^{\circ}$ to $30^{\circ}$ for a 4 -hr incubation had no effect on the 
total incorporation of ${ }^{14} \mathrm{C}$ from $\left[{ }^{14} \mathrm{C}\right]$ glucose into the protozoa but increased the incorporation into the pool by $20 \%$ at low (i.e. below the break shown in Fig. 2) glucose concentrations only. Prolonged incubation at $20^{\circ}$ was not possible because of death of the protozoa; but in experiments of $30 \mathrm{~min}$. duration the total incorporation at low glucose concentrations was decreased by $35 \%$ as compared with incubation at $40^{\circ}$ with no change in the amount of ${ }^{14} \mathrm{C}$ in the pool. At high glucose concentrations lowering the temperature to $20^{\circ} \mathrm{had}$ no effect on the total incorporation of ${ }^{14} \mathrm{C}$ but increased the proportion of the ${ }^{14} \mathrm{C}$ present in the pool from $78 \%$ to $88 \%$. These results show that at all glucose concentrations the reactions by which glucose in the pool was incorporated into particulate matter were more sensitive to a decrease in temperature than the reactions by which glucose was incorporated into the pool.

Effect of particulate matter on uptake of glucose. Holter (1965) showed that in Amoeba proteus which was taking up protein particles from the medium by pinocytosis only $5 \%$ of the liquid in which the protein was suspended was taken up at the same time. Since Entodinium caudatum engulfs particulate matter and can take up $200 \mathrm{bacteria} / \mathrm{min}$. (Coleman, $1964 \mathrm{~b}$ ) it was of interest to determine the effect of inert particulate matter on the rate of glucose incorporation. The material used was polystyrene latex particles of diam. I $3 \mu$ (Dow Chemical Co., Midland, Michigan, U.S.A.) which have been shown by light and electron microscopy to be engulfed by the protozoa. In the presence of $0.33 \%$ polystyrene latex $\left(5.5 \times 10^{9}\right.$ particles $/ \mathrm{ml}$. $)$ there was usually a small and variable increase (o to $25 \%$ ) in the incorporation of ${ }^{14} \mathrm{C}$ from 2 to $130 \mathrm{~mm}-\left[{ }^{14} \mathrm{C}\right] g l u c o s e$ into the protozoa. However, in one experiment the stimulation increased from $28 \%$ in the presence of $130 \mathrm{~mm}-\left[{ }^{14} \mathrm{C}\right]$ glucose to $\mathrm{I} 20 \%$ with $4 \mathrm{mM}$ $\left[{ }^{4} \mathrm{C}\right]$ glucose. The actual stimulation probably depended on how full of starch grains the protozoa were on harvesting. Latex at $0.03 \%$ gave negligible stimulation at any glucose concentration. Since with the higher latex concentration the protozoa were completely filled with particles after incubation for $20 \mathrm{~min}$. and many were still free in the medium, the stimulation obtained must have been the maximum possible associated with the uptake of particulate matter. It is therefore considered that in standard washed suspension experiments particle-stimulated incorporation was unimportant.

Effect of glucose incorporation on the level of glucose in the pool. It has been shown above that glucose in the medium was incorporated into the protozoa and that the freshly harvested protozoon had free glucose in its pool. It was therefore of interest to investigate the effect of glucose incorporation on the concentration of glucose in the pool. Figure 3 is a time course for the effect on the glucose in the pool of the incorporation of ${ }^{14} \mathrm{C}$ from $83 \mathrm{~mm}-\left[{ }^{14} \mathrm{C}\right]$ glucose and shows that after incubation for $6 \mathrm{hr}$ ${ }^{14} \mathrm{C}$ equivalent to $0.18 \mu$ mole glucose was incorporated into a pool that contained $0.20 \mu$ mole glucose; $75 \%$ (i.e. $0.135 \mu$ mole) of the ${ }^{14} \mathrm{C}$ incorporated was present as glucose. This shows that over $60 \%$ of the glucose in the pool was replaceable by glucose from the medium without increase in the concentration of glucose in the pool. At external glucose concentrations over about $0.08 \mathrm{M}$ the incorporation of $\left[{ }^{14} \mathrm{C}\right]$ glucose was accompanied by an increase in the total glucose in the cell (Fig. 4). Inhibition of some of the metabolic activities of the protozoa by lowering the temperature to $2 \mathrm{I}^{\circ}$ or by adding $0.67 \mathrm{~mm}$-iodoacetate abolished the phase at lower glucose concentrations where the concentration in the pool was not affected by glucose incorporation; for every mole of glucose incorporated there was a corresponding. increase in pool glucose over the entire concentration range tested (Fig. 4). The 
concentration of glucose in the pool usually decreased on incubation of freshly harvested protozoa (Table 2) but both these treatments produced an increase in pool glucose even in the absence of added glucose (Fig. 4). These results are explicable if the level of glucose in the pool represents a steady state balance between an input of glucose by hydrolysis of maltose derived from intracellular starch or from the medium, and a loss of glucose by release into the medium or conversion into protozoal or bacterial polysaccharide. Inhibition of the biosynthetic reactions by lowering the temperature or the addition of iodoacetate would tend to increase the glucose concentration in the pool because the rate of removal of glucose was decreased without alteration in the

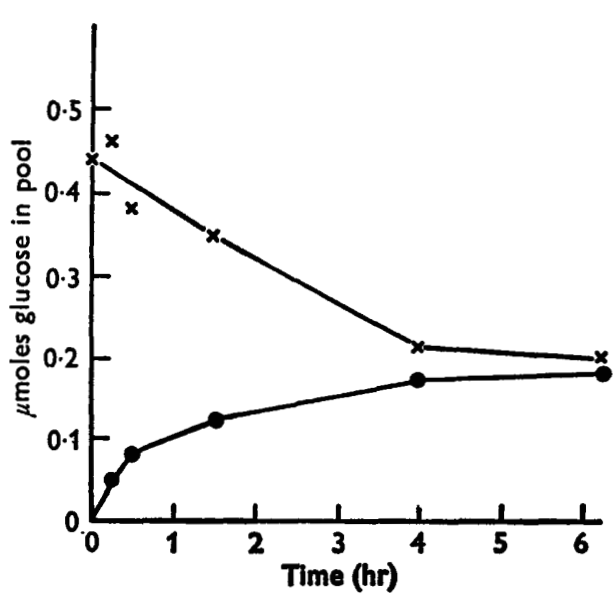

Fig. 3

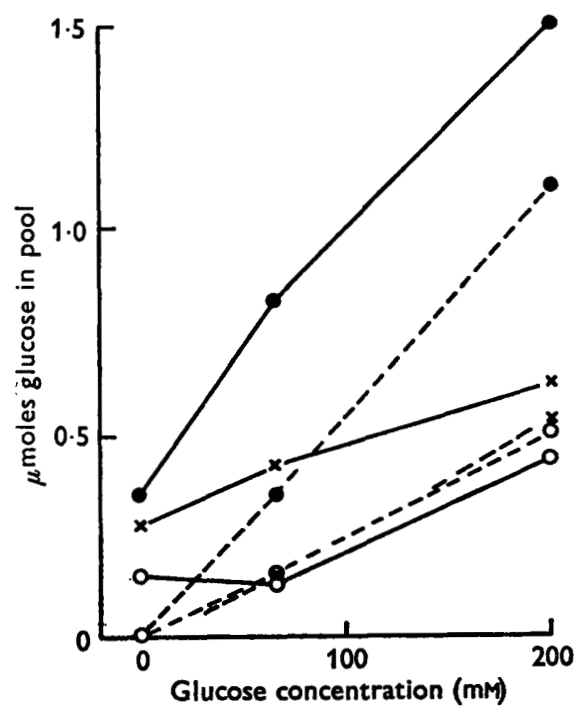

Fig. 4

Fig. 3. Effect of incubation in the presence of $80 \mathrm{~mm}-\left[{ }^{14} \mathrm{C}\right]$ glucose on the concentration of glucose in the pool of Entodinium caudatum. $\times-\times$, Total glucose in pool as determined by glucose oxidase method; $-\longrightarrow,\left[{ }^{14} \mathrm{C}\right]$ glucose incorporated into pool as calculated from ${ }^{14} \mathrm{C}$ found in pool and known specific activity of glucose added initially.

Fig. 4. Effect of glucose concentration in the medium on the incorporation of $\left[{ }^{14} \mathrm{C}\right]$ glucose and the concentration of glucose in the protozoal pool in $1.7 \times 10^{6}$ protozoa contained in $1.5 \mathrm{ml}$. during a $20 \mathrm{~min}$. incubation. - , Total pool glucose as determined by glucose oxidase method; - - - $\left[{ }^{14} \mathrm{C}\right] \mathrm{g}$ lucose in the pool calculated from the ${ }^{14} \mathrm{C}$ found in the pool and the known specific activity of the glucose added initially; $O$, in presence of $0.67 \mathrm{mM}$ iodoacetate at $40^{\circ} ; O$, incubated at $40^{\circ}$ in absence of iodoacetate; $x$, incubated at $21^{\circ}$ in absence of iodoacotate. Initial pool glucose was $0.16 \mu$ moles.

rate of input of glucose. With normal protozoa incubated at $40^{\circ}$ in the presence of a low concentration of glucose the absence of any increase in pool glucose could be explained by $(a)$ entry of $\left[{ }^{4} \mathrm{C}\right]$ glucose by exchange with $\left[{ }^{2} \mathrm{C}\right]$ glucose in the pool or (b) a feed-back mechanism in which the concentration of glucose controls the activity of the maltase which hydrolyses maltose to glucose, but not the rate of glucose uptake from the medium.

In an attempt to show an exchange reaction the protozoa were pre-incubated with 0.02 or $100 \mathrm{mM}-\left[{ }^{4} \mathrm{C}\right]$ glucose for $50 \mathrm{~min}$., then washed three times in salt solution and incubated in the presence or absence of $\left[{ }^{2} \mathrm{C}\right]$ glucose for 5 or $30 \mathrm{~min}$. If an exchange 
reaction occurred, the release of ${ }^{14} \mathrm{C}$ from the protozoal pool into the medium would be markedly stimulated by the presence of $\left[{ }^{2} \mathrm{C}\right]$ glucose in the medium. The protozoa labelled at a high glucose concentration released ${ }^{14} \mathrm{C}$ progressively into the medium and there was a decline in the ${ }^{14} \mathrm{C}$ in both the pool and the pellet fractions, but the rate of loss from the pool was not affected by the presence in the medium of 6.7 or $67 \mathrm{mM}$ $\left[{ }^{12} \mathrm{C}\right]$ glucose. With protozoa labelled at low glucose concentration there was a progressive loss of ${ }^{14} \mathrm{C}$ from the pool into the protozoal pellet and the medium but neither of these reactions was affected by the presence of $\left[{ }^{12} \mathrm{C}\right]$ glucose. It is therefore considered unlikely that the incorporation of $\left[{ }^{14} \mathrm{C}\right]$ glucose occurred by an exchange reaction. The effect of glucose concentration on the rate of hydrolysis of maltose is considered below.

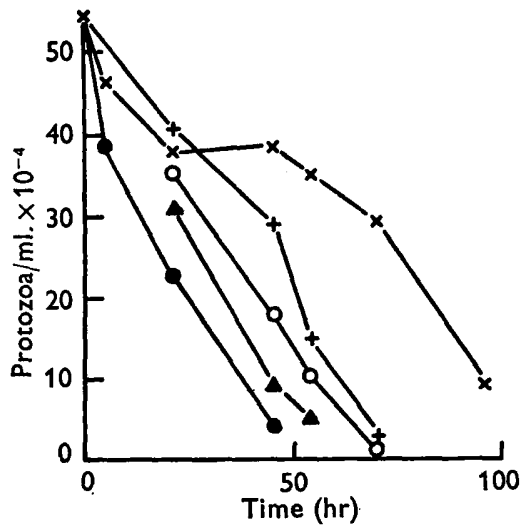

Fig. 5

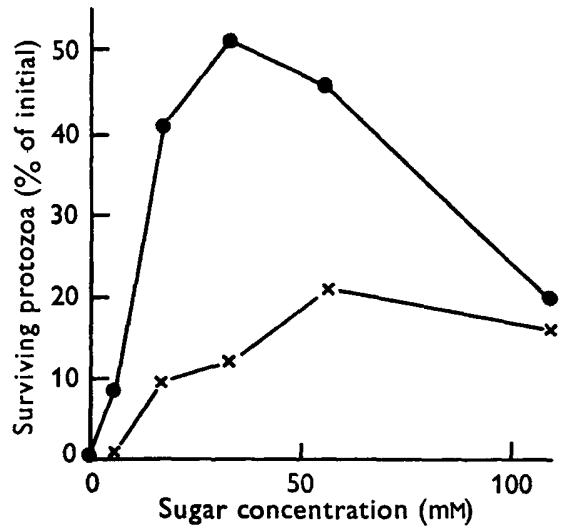

Fig. 6

Fig. 5. Effect of various carbohydrates on the survival of freshly harvested Entodinium caudatum incubated anaerobically in the presence of $10 \%(\mathrm{v} / \mathrm{v})$ autoclaved rumen fluid (PARF, Coleman, 1964a) +1000 units penicillin $\mathrm{G} / \mathrm{ml} .+400 \mu \mathrm{g}$. neomycin sulphate $/ \mathrm{ml}$. - No added carbohydrate; $\Delta-\Delta, 22 \mathrm{~mm}$-galactose; $\mathrm{O}-\mathrm{O}, 22 \mathrm{~mm}$-glucose; $+\longrightarrow+, 11 \mathrm{~mm}$-maltose; $\times \longrightarrow \times, 0.4 \%$ soluble starch.

Fig. 6. Effect of concentration of maltose (-) and glucose $(x-x)$ on the survival of freshly harvested Entodinium caudatum incubated anaerobically in the presence of $10 \%$ (v/v) autoclaved rumen fluid (PARF) +1000 units penicillin $\mathrm{G} / \mathrm{ml}+400 \mu \mathrm{g}$. neomycin sulphate/ml. for $50 \mathrm{hr}$.

\section{Metabolism of maltose}

Effect on protozoal survival. Figure 5 shows time courses for the effect of various carbohydrates on the survival of freshly harvested and washed Entodinium caudatum incubated anaerobically in the presence of penicillin + neomycin + autoclaved rumen fluid (PARF). Although all the protozoa died in 5 days, soluble starch or maltose were more effective in prolonging the life of the ciliates than were either glucose or galactose. The greater effectiveness of maltose was observed at all concentrations (Fig. 6) whether these were expressed per molecule of maltose or per molecule of glucose. This suggests a difference in mode of uptake or metabolism and not that maltose acts because it contains two molecules of glucose. In experiments with $\left[{ }^{14} \mathrm{C}\right]$ glucose and maltose it was possible to show that their greater effectiveness at high concentrations was not due to the complete utilization of sugars at low concentrations. In no culture in the experiment shown in Fig. 6 was more than $30 \%$ of the sugar 
utilized. Of the sugar that was metabolized less than $2 \%$ appeared in the protozoa and over $80 \%$ was converted into material that was volatile on the addition of acid but retained on a planchet in the presence of $\mathrm{NaOH}$, i.e. probably a fatty acid.

Incorporation of maltose. When incubated anaerobically in the presence of equimolar concentrations of glucose and maltose in the absence of antibiotics, Entodinium caudatum incorporated into the pool maltose-carbon over four times as rapidly as glucose-carbon. In one experiment $7.4 \times 10^{5}$ protozoa incubated in the presence of $0.67 \mathrm{~mm}$-sugar incorporated in $\mathrm{I} \mathrm{hr} 0.87 \times 10^{-2} \mu$ moles glucose and $\mathrm{I} .96 \times \mathrm{IO}^{-2} \mu$ moles maltose. This higher incorporation of maltose was only apparent at low sugar concentrations (Fig. 7) because on a reciprocal plot of incorporation against sugar concentration both curves showed a break at $2.8 \mathrm{~mm}$ and above this the incorporation of both sugars was the same. The maximum 'active' uptake of maltose into the pool as calculated by extrapolation of the right-hand part of the curve to the ordinate was $0.034 \mu \mathrm{moles} / \mathrm{hr} / \mathrm{IO}^{6}$ protozoa, as compared with $0.046 \mu \mathrm{moles} / \mathrm{hr} / 10^{6}$ protozoa for glucose. However the substrate concentration for half maximum uptake was $3.6 \mathrm{~mm}$ for glucose and $0.85 \mathrm{~mm}$ for maltose. There was also an increased (40\%) incorporation of carbon into the hot TCA-soluble fraction of the broken-cell pellet in the presence of maltose, but this was only into the bacterial fraction, and equimolar amounts of glucose and maltose were incorporated into protozoal polysaccharide at all concentrations. This result can be explained by the observation that although the Proteus mirabilis inside the protozoa does not incorporate maltose-carbon Klebsiella aerogenes incorporated maltose-carbon at over three times the rate for glucose-carbon when the sugars were present singly at equimolar concentration.

Effect of inhibitors and temperature. As with glucose incorporation, the above results suggested that there may be an active (predominant at low concentration) and a passive (predominant at high concentration) uptake of maltose. An attempt was therefore made to see whether the active process could be inhibited by the use of other sugars or by decreasing the temperature. Like the inhibitors of glucose incorporation, the inhibitors of maltose incorporation could be divided into two groups based on their effect when added at $25 \mathrm{~mm}$ in experiments of $3 \mathrm{hr}$ duration. Those of group I which contained only 2-deoxyglucose inhibited the incorporation of ${ }^{14} \mathrm{C}$ from $\left[{ }^{14} \mathrm{C}\right]$ maltose at all concentrations, whereas those of group 2 (galactose, glucose, mannose, cellobiose) inhibited only at concentrations below the break shown in Fig. 7. Similar results were obtained for incorporation into the pool alone and the relative uptakes into the pool and the broken-cell pellet were the same in the presence and absence of inhibitors. In contrast, when the protozoa were incubated at $30^{\circ}$ there was an increased incorporation into the pool, especially at substrate concentrations of 0.5 to $1 \cdot 2 \mathrm{mM}$ and the position of the break in the curve of incorporation/substrate concentration on a reciprocal plot was moved to a lower concentration (Fig. 8). As this result was only obtained clearly after 4 to $5 \mathrm{hr}$ incubation, the experiment was made in the presence of antibiotics in order to prevent the growth of bacteria. Incorporation into the pellet fraction of the protozoa was decreased by 20 to $25 \%$ at all substrate concentrations, so that the total incorporation into the protozoa was unchanged or slightly stimulated. The increase in the concentration of ${ }^{14} \mathrm{C}$ in the pool shows that the mechanisms for the incorporation of $\left[{ }^{4} \mathrm{C}\right]$ maltose into the pool were less sensitive to change in temperature than those for the removal of ${ }^{14} \mathrm{C}$ into the pellet fractions. The change in the position of the break in the curve for incorporation into the pool shown in Fig. 8 means that 
the 'passive' uptake reaction was predominant over a longer concentration range at the lower temperature; this suggested that it was less sensitive to change of temperature than the 'active' process. The uniform effect of the temperature change on incorporation of ${ }^{14} \mathrm{C}$ into the pellet fractions at all substrate concentrations may indicate that only the $\left.{ }^{[14} \mathrm{C}\right]$ maltose taken up by the active process was incorporated into the pellet fractions. If this were not so, then the increased concentration of ${ }^{14} \mathrm{C}$ in the pool might be expected to nullify the effect of the lower temperature on incorporation of ${ }^{14} \mathrm{C}$ into the pellet fractions from the pool.

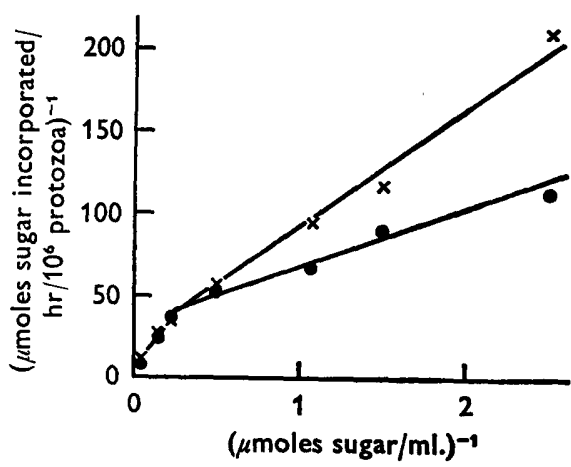

Fig. 7

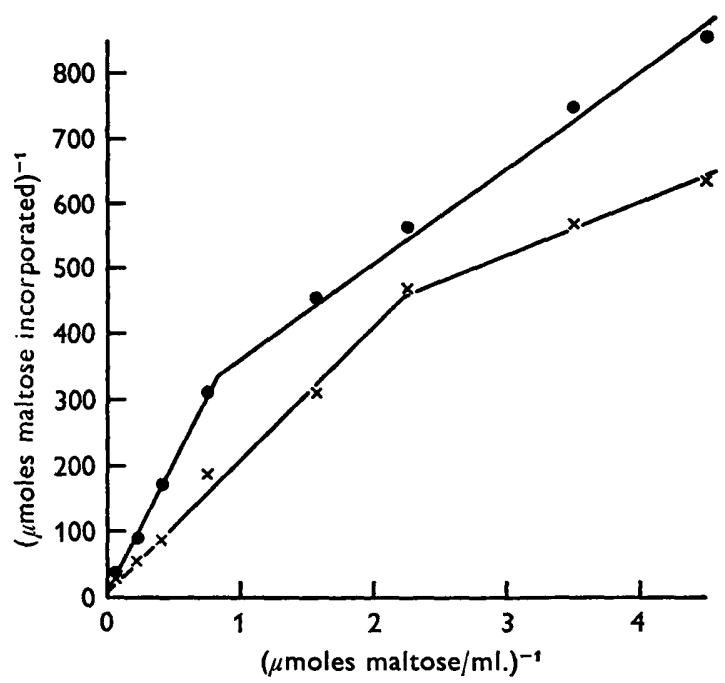

Fig. 8

Fig. 7. Effect of substrate concentration on the incorporation of $\left[\mathrm{U}-{ }^{\mathbf{1 4}} \mathrm{C}\right]$ maltose $(-$ and [U-14C]glucose $(x-x)$ by Entodinium caudatum incubated anaerobically in the absence of antibiotics for $20 \mathrm{~min}$.

Fig. 8. Effect of incubation temperature on the incorporation of ${ }^{14} \mathrm{C}$ from [U- $\left.{ }^{14} \mathrm{C}\right] \mathrm{maltose}$ into the pool of Entodinium caudatum incubated anaerobically in the presence of 1000 units penicillin $\mathrm{G} / \mathrm{ml}$. $+400 \mu \mathrm{g}$. neomycin sulphate $/ \mathrm{ml}$. for $5 \mathrm{hr}$. - , Incubated at $40^{\circ}$; $x-x$, incubated at $30^{\circ}$.

Effect of antibiotics and of cell breakage. The incorporation of ${ }^{14} \mathrm{C}$ from $0.7 \mathrm{~mm}-$ $\left[{ }^{14} \mathrm{C}\right]$ maltose into the pool of protozoa incubated in absence of antibiotics was markedly decreased by pre-incubation for $20 \mathrm{hr}$ of protozoa with I000 units penicillin/ $\mathrm{ml} .+400 \mu \mathrm{g}$. neomycin sulphate/ml. (Fig. 9). Similar results were obtained with glucose and with both sugars incorporation was progressive for over $4 \mathrm{hr}$ without pre-incubation, whereas with antibiotic-treated protozoa incorporation reached a maximum after $20 \mathrm{~min}$. and then decreased, until after $\mathrm{I} \mathrm{hr}$ the incorporation was less than $15 \%$ of that into untreated protozoa. At high sugar concentrations ( $20 \mathrm{mM})$ the pre-incubation had no inhibitory effect on the incorporation of ${ }^{14} \mathrm{C}$ from $\left[{ }^{14} \mathrm{C}\right]$ glucose or maltose both of which were incorporated to the same extent on a molar basis. This observation suggested that the antibiotics affected the 'active' uptake only. In contrast, pre-incubation of the protozoa with penicillin and neomycin decreased incorporation of ${ }^{14} \mathrm{C}$ from high concentrations of $\left[{ }^{14} \mathrm{C}\right]$ maltose into the pellet fractions to $30 \%$ of that with normal untreated protozoa; at low maltose concentrations incorporation 
was decreased to $\mathrm{I}$ to $2 \%$. This suggested, as before, that only ${ }^{14} \mathrm{C}$ taken up by the 'active' process could be incorporated into the pellet fractions. Breakage of the protozoa before incubation with $\left[{ }^{14} \mathrm{C}\right]$ maltose decreased the incorporation of ${ }^{14} \mathrm{C}$ into the pellet by between $41 \%$ (at 0.3 mM-maltose) and $72 \%$ (at 15 mM-maltose).

Nature of products in protozoal pool. Figure Io shows a time course for the incorporation of ${ }^{14} \mathrm{C}$ from $\left[{ }^{14} \mathrm{C}\right]$ maltose into various pool constituents. There was a rapid incorporation of maltose into the pool and breakdown of this maltose to glucose during the first minute of incubation. Thereafter the amounts of these $\left[{ }^{14} \mathrm{C}\right]$ sugars

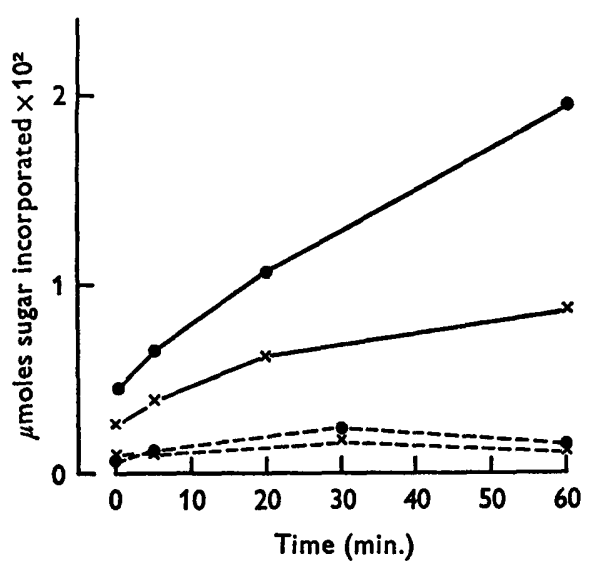

Fig. 9

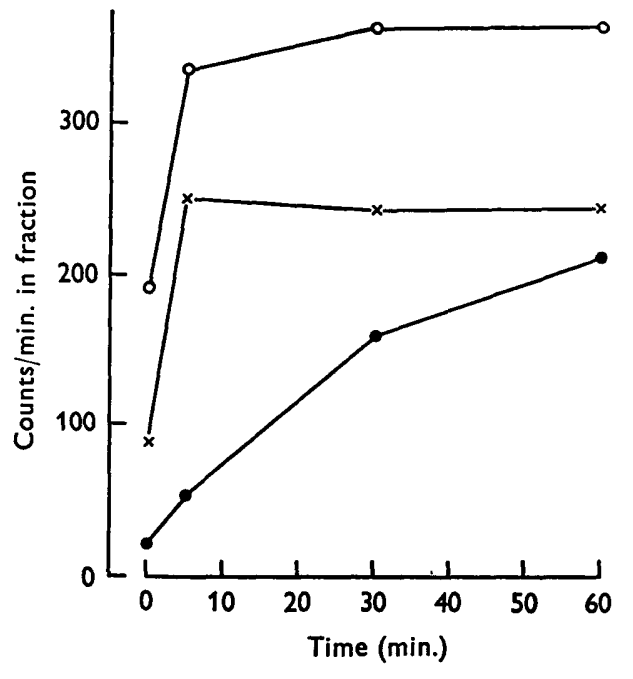

Fig. 10

Fig. 9. Effect of pre-incubation of Entodinium caudatum for $20 \mathrm{hr}$ in the presence of 1000 units penicillin $\mathrm{G} / \mathrm{ml} .+400 \mu \mathrm{g}$. neomycin sulphate $/ \mathrm{ml}$. on the uptake of ${ }^{14} \mathrm{C}$ from [U- $\left.{ }^{14} \mathrm{C}\right]$ maltose $(O)$ and [U-14 C]glucose $(x)$ in the absence of antibiotics.,$- 4.3 \times 10^{5} / \mathrm{ml}$. freshly harvested protozoa; - - - , 4.0 $\times 10^{6} / \mathrm{ml}$. protozoa pre-incubated with antibiotics.

Fig. 10. Incorporation of ${ }^{14} \mathrm{C}$ from $0.15 \mathrm{~mm}-\left[\mathrm{U}-{ }^{14} \mathrm{C}\right]$ maltose into various fractions in the pool of Entodinium caudatum. $\mathrm{O}-\mathrm{O}$, Into glucose; $\times-\times$, into maltose; -0 , into hexose phosphate.

increased more slowly to reach a maximum after $5 \mathrm{~min}$., after which time the quantities remained constant. In contrast, there was a steady increase throughout the experiment in the amount of glucose phosphate present. During incubation for $5 \mathrm{hr} / 7 \mathrm{~mm}-2-$ deoxyglucose inhibited incorporation into all pool constituents equally, whereas glucose specifically inhibited incorporation into pool glucose and decreased the amount of maltose in the medium that was hydrolysed to glucose from 29 to $3 \%$. The relative incorporation into the various pool constituents was the same at $30^{\circ}$ and $40^{\circ}$ and at high and low maltose concentrations.

\section{Metabolism of other sugars}

Ribose. Washed suspensions of Entodinium caudatum incubated anaerobically in the presence of penicillin + neomycin incorporated ${ }^{14} \mathrm{C}$ from $\left[\mathrm{I}-{ }^{14} \mathrm{C}\right]$-D-ribose progressively for at least $6 \mathrm{hr}$. After incubation for $5 \mathrm{hr} 48 \%$ of the ${ }^{14} \mathrm{C}$ incorporated by the protozoa was present in the pool, $5 \%$ in the hot TCA-soluble fraction of the broken-cell 
supernatant fluid, $25 \%$ in the hot TCA-soluble fraction of the broken-cell pellet and $6 \%$ in the combined protein fractions of the protozoa. The ${ }^{14} \mathrm{C}$ in the pool was present as ribose only. After further hydrolysis of the hot TCA-soluble fraction of the pellet in $\mathrm{N}-\mathrm{HCl}$ for $\mathrm{I} \mathrm{hr}$ at $100^{\circ}$ all the ${ }^{14} \mathrm{C}$ was present as glucose. It was not possible to identify $\left[{ }^{14} \mathrm{C}\right]$ ribose in either of the hot TCA-soluble fractions.

The pellet fraction of protozoa that had incorporated ${ }^{14} \mathrm{C}$ from $\left[{ }^{14} \mathrm{C}\right]$ ribose was fractionated by centrifugation through $2.0 \mathrm{M}$-sucrose (as described above) in order to investigate the incorporation of ${ }^{14} \mathrm{C}$ into protozoal polysaccharide and intracellular bacteria. Of the ${ }^{14} \mathrm{C}$ in the pellet, $40 \%$ and $70 \%$ were present in the protozoal polysaccharide on incubation with $0.04 \mathrm{mM}$ and $67 \mathrm{mM}\left[{ }^{14} \mathrm{C}\right]$ ribose, respectively. Since glucose was the only combined $\left[{ }^{14} \mathrm{C}\right]$ sugar found in the pellet fraction this suggested that both the protozoa and the bacteria converted ribose into glucose.

As with $\left.{ }^{14} \mathrm{C}\right]$ glucose and maltose there was a break in the curve for incorporation of ${ }^{14} \mathrm{C}$ from $\left[{ }^{14} \mathrm{C}\right]$ ribose/substrate concentration on a reciprocal plot; for ribose this was at $3 \mathrm{~mm}$. The maximum rate of uptake of ribose calculated by extrapolation of the right-hand part of the curve was $0.024 \mu$ moles $/ 4 \mathrm{hr} / 10^{6}$ protozoa. During a $4-\mathrm{hr}$ period $25 \mathrm{mM}-\mathrm{D}$-glucose inhibited the incorporation of ${ }^{14} \mathrm{C}$ from $0.3 \mathrm{mM}-\left[{ }^{14} \mathrm{C}\right]$ ribose by $23 \%$ but had no effect at high ribose concentrations. 2-Deoxyglucose at $25 \mathrm{~mm}$ inhibited incorporation by $33 \%$ at $0.3 \mathrm{~mm}$-ribose and by $22 \%$ at $0.05 \mathrm{M}$-ribose. In contrast to the results on the incorporation of $\left[{ }^{14} \mathrm{C}\right]$ glucose, breakage of the protozoa before incubation or changing the incubation temperature to $30^{\circ}$ decreased the incorporation of ${ }^{14} \mathrm{C}$ from $0.3 \mathrm{~mm}-\left[{ }^{14} \mathrm{C}\right]$ ribose to 28 and $73 \%$, respectively.

Galactose. ${ }^{14} \mathrm{C}$ from $\left[\mathrm{I}^{14} \mathrm{C}\right]$-D-galactose was incorporated by washed protozoal suspensions and the curve for incorporation of ${ }^{14} \mathrm{C} /$ substrate concentration on a reciprocal plot showed a break at $\mathrm{I} \cdot 2 \mathrm{mM}$-galactose. The maximum rate of galactose uptake calculated by extrapolation of the right hand part of the curve to the ordinate was $0.023 \mu \mathrm{mole} / \mathrm{hr} / \mathrm{lol}$ protozoa. After incubation for $4 \mathrm{hr} 25 \%$ of the protozoal ${ }^{14} \mathrm{C}$ was present in the pool and $5 \mathrm{I} \%$ in the hot TCA-soluble fraction of the broken-cell pellet. The only ${ }^{14} \mathrm{C}$-labelled compound in the pool and in the hot TCA-soluble fraction after hydrolysis in $\mathrm{N}-\mathrm{HCl}$ for $\mathrm{I} \mathrm{hr}$ at $100^{\circ}$ was glucose. Of the ${ }^{14} \mathrm{C}$ in this latter fraction $30 \%$ was associated with the protozoal polysaccharide at low external galactose concentrations and $50 \%$ at high concentrations. As shown in Fig. 5, galactose has little beneficial effect on the survival of protozoa in the presence of antibiotics.

Sucrose. ${ }^{14} \mathrm{C}$ from $0.3 \mathrm{mM}-\left[\mathrm{U}-{ }^{14} \mathrm{C}\right]$ sucrose was incorporated into the protozoa at two-thirds of the rate for ${ }^{14} \mathrm{C}$ from $\left[{ }^{4} \mathrm{C}\right]$ maltose at the same concentration. The break in the curve for incorporation of ${ }^{14} \mathrm{C} /$ substrate concentration on a reciprocal plot was $2 \mathrm{~mm}$.

\section{Permeability of protozoa to ${ }^{14} \mathrm{C}$-labelled sugars}

It has been shown (Coleman, 1967a) that 50 to $60 \%$ of the packed cell volume of Entodinium caudatum is impermeable to amino acids in experiments up to $5 \mathrm{~min}$. duration. It was of interest to determine whether the same is true with sugars and whether or not this is affected by different temperatures of incubation. The experiments were done by a method similar to that described by Coleman (1967a). This involved preparing by the standard method a very thick protozoal suspension such that on centrifugation the packed protozoal pad was about half the total volume. Samples $\left(0.2 \mathrm{ml}\right.$.) of $\left[{ }^{14} \mathrm{C}\right]$ sugar (at minimum concentration of $5 \mathrm{mM}$ ) were mixed with 
$\mathrm{I} \cdot 0 \mathrm{ml}$. protozoal suspension or $\mathrm{I} \cdot 0 \mathrm{ml}$. salts solution in a $10 \mathrm{ml}$. graduated conical centrifuge tube and incubated for $2 \mathrm{~min}$. The tubes were then centrifuged for $30 \mathrm{sec}$. from starting, on a bucket-head centrifuge (final speed equivalent to $300 \mathrm{~g}$ ). The volume of the protozoal pellet was measured, then all the supernatant fluid removed and $0.1 \mathrm{ml}$. of it used for the estimation of ${ }^{14} \mathrm{C}$. The sides of the tube were wiped with filter paper to remove free medium and then the protozoal pellet suspended in salts solution to a total volume of $5 \mathrm{ml}$.; $0.25 \mathrm{ml}$. of this suspension was used for the estimation of the total ${ }^{14} \mathrm{C}$ associated with unwashed protozoa. The suspension was then centrifuged, the protozoa washed once more in salt solution and treated as described under Methods for the estimation of ${ }^{14} \mathrm{C}$ in washed protozoa and in the protozoal pool. In contrast to the results obtained two years ago and reported previously (Coleman, $1967 a$ ) it was now possible to incubate $E$. caudatum in a thick suspension at $40^{\circ}$ for up to I hr without the protozoa showing signs of disintegration. The cause of this change in protozoal behaviour is unknown but it enabled the effect of temperature on protozoal permeability to be measured with greater accuracy. The results were calculated as follows. The total amount of ${ }^{14} \mathrm{C}$ added to the system in the presence or absence of protozoa was calculated from the ${ }^{14} \mathrm{C}$ present in $0.1 \mathrm{ml}$. of medium in the absence of protozoa. From this value and the amount of ${ }^{14} \mathrm{C}$ present in $0 \cdot \mathrm{I} \mathrm{ml}$. supernatant fluid above the protozoa, the volume of liquid available to the sugar in the presence of protozoa was calculated. The difference between this value and the total volume of liquid gave the volume impermeable to the sugar and this was compared with the volume of protozoa present. The percentage of the protozoal volume impermeable to the sugar was given by

$$
\text { I00 } \times[\text { total volume }-(A / \mathrm{IO} B)] / \text { protozoal volume, }
$$

where in counts/min., $A=$ total amount of ${ }^{14} \mathrm{C}$ and $B={ }^{14} \mathrm{C}$ present in $0.1 \mathrm{ml}$. supernatant fluid in the presence of protozoa.

Under these conditions $63 \pm 12 \%$ (for seven different batches of protozoa; range 46 to $81 \%$ ) of the packed-cell pad volume was impermeable to glucose at $20^{\circ}$. In an experiment in which $27 \%$ of the protozoal volume was permeable to $0.001 \mathrm{M}^{-14} \mathrm{C}$ glucose at $20^{\circ}, 4 \%$ of this glucose was not removable by washing the protozoa twice in salt solution. If this glucose was isolated in a cellular compartment of the protozoa, then this compartment occupied only $1 \cdot 7 \%$ of the volume of the protozoon. On incubation of the protozoa for $5 \mathrm{~min}$. at $40^{\circ}$ the apparent mean impermeable volume decreased to $46 \pm 10 \%$; but since the decrease in the ${ }^{14} \mathrm{C}$ in the presence of protozoa was due to a loss of ${ }^{14} \mathrm{C}$ from the complete system, presumably because of the formation of ${ }^{14} \mathrm{CO}_{2}$, this increased permeability was probably an artifact. However, the proportion of the protozoal ${ }^{14} \mathrm{C}$ that was not removable from the pool by washing increased to $7 \%$. At high glucose concentrations (i.e. $70 \mathrm{~mm}$ ) the permeable volume remained at the lower value even after $5 \mathrm{~min}$. incubation at $40^{\circ}$, and $5 \%$ of the glucose associated with the protozoa was not removed from the pool by washing. Similar results were obtained at low glucose concentrations $(\mathrm{I} .0 \mathrm{mM})$ in the presence of I4 mM-2-deoxyglucose. However, in the presence of $0.8 \mathrm{~mm}$-iodoacetate, although the impermeable volume remained unchanged, the proportion of the total ${ }^{14} \mathrm{C}$ in unwashed protozoa that could not be removed from the pool by washing increased to $27 \%$ after incubation for $5 \mathrm{~min}$. If this glucose was isolated in a compartment of the protozoa at its original concentration it must have occupied i I \% of protozoal volume. 


\section{Studies on some protozoal enzymes}

A possible explanation for the comparative ineffectiveness of glucose and maltose compared with starch in maintaining protozoal life would be the absence of a glucokinase (ATP: D-glucose-6-phospho-transferase, EC 2 . 7 . I .2) and a maltose phosphorylase (maltose: orthophosphate glucosyltransferase, EC 2.4. I.8) associated with the presence of an $\alpha$ glucan phosphorylase ( $\alpha$ I,4 glucan: orthophosphate phosphorylase, EC 2.4 I . I). Under these conditions glucose could not be phosphorylated to glucose6-phosphate, the glucose of maltose could not be phosphorylated either directly or after liberation in the free form, but starch could undergo a phosphorolysis to glucoseI-phosphate which could be metabolized by the enzymes of the glycolytic pathway. The presence of these enzymes in the protozoal broken cell supernatant fluid was therefore investigated.

\section{Table 5. Phosphorylase activity of Entodinium caudatum}

The basal incubation medium contained $1.5 \mathrm{ml}$. $0.1 \mathrm{M}-\beta \beta^{\prime}$-dimethylglutarate buffer (pH 6.4), $0.1 \mathrm{ml}$. I mM-phosphate, $0.1 \mathrm{ml}$. ${ }^{\text {s2}} \mathrm{P}$-inorganic phosphate (I0 $\mu \mathrm{C} / \mathrm{ml}$.) plus the additions given below. $95 \%(\mathrm{v} / \mathrm{v}) \mathrm{N}_{2}+5 \%(\mathrm{v} / \mathrm{v}) \mathrm{CO}_{2}$ was bubbled through the medium for $2 \mathrm{~min}$. (except where cysteine was omitted from the medium) before the addition of $0.2 \mathrm{ml}$. of broken protozoal preparation. The tubes were then gassed for a further $10 \mathrm{sec}$. before sealing with a rubber bung and incubation at $39^{\circ}$; total volume was $3 \mathrm{ml}$. At the end of the experiment inorganic phosphate was precipitated with sodium fluoride and magnesia mixture (see Methods) and a sample of the supernatant fluid plated out for the estimation of ${ }^{82} \mathbf{P}$.

\begin{tabular}{|c|c|c|c|c|}
\hline \multicolumn{3}{|c|}{ Additions to the basal medium } & \multicolumn{2}{|c|}{$\begin{array}{l}\text { Radioactivity } \\
\text { (counts/min.) }\end{array}$} \\
\hline $\begin{array}{c}2 \% \text { soluble } \\
\text { starch }\end{array}$ & $\begin{array}{l}\text { I \% L- } \\
\text { cysteine }\end{array}$ & $\begin{array}{r}\text { Protozoal } \\
\text { preparation }\end{array}$ & Initial & $30 \mathrm{~min}$ \\
\hline $0.1 \mathrm{ml}$ & $0.2 \mathrm{ml}$. & BCS & 200 & 1500 \\
\hline- & $0.2 \mathrm{ml}$. & BCS & 180 & 480 \\
\hline $0.1 \mathrm{ml}$. & - & BCS & 190 & 900 \\
\hline $0.1 \mathrm{ml}$ & $0.2 \mathrm{ml}$ & - & 200 & 220 \\
\hline- & $0.2 \mathrm{ml}$ & SP & 250 & 2010 \\
\hline $0.1 \mathrm{ml}$. & $0.2 \mathrm{ml}$ & $\mathbf{S P}$ & 300 & 3520 \\
\hline- & $0.2 \mathrm{ml}$ & BCP & 270 & 900 \\
\hline $0.1 \mathrm{ml}$ & $0.2 \mathrm{ml}$ & BCP & 130 & 1940 \\
\hline
\end{tabular}

$\mathbf{S P}=$ ultrasonically treated protozoa $; \mathrm{BCS}=$ broken-protozoal supernatant fluid $; \mathrm{BCP}=$ brokenprotozoal pellet.

$\alpha$-Glucan phosphorylase. Under the conditions described in Methods the values obtained before incubation and in the absence of enzyme represented $0.5 \%$ of the total radioactivity and the amount of soluble ${ }^{32} \mathrm{P}$ usually increased linearly up to Io times during a 2-hr incubation with enzyme (Table 5). When the sodium fluoride that was normally added at the end of the incubation was present throughout, it has been shown on a reciprocal plot of enzyme activity/phosphate concentration to act as a competitive inhibitor (Dixon \& Webb, 1964). The effect of cysteine on enzyme activity was very variable and its omission decreased this by 0 to $50 \%$. In the initial experiments the buffer used was $0.03 \% \mathrm{NaHCO}_{3}+5 \%$ (v/v) $\mathrm{CO}_{2}+0.5 \% \mathrm{NaCl}$ (pH 6.64). The buffering capacity of this mixture was poor: 0.1 I M-malate, $0.04 \mathrm{M}$ citrate, $0.04 \mathrm{M}$-tris and $0.05 \mathrm{M}$ - $\beta \beta^{\prime}$-dimethylglutarate buffers were tested as possible replacements. Phosphorylase activity was detected in the presence of each of these buffers 
but with the exception of dimethylglutarate the optimum $\mathrm{pH}$ value was at the limit of their buffering ranges. In the presence of $\beta \beta^{\prime}$-dimethylglutaric acid $+\mathrm{NaOH}$ buffer the optimum was $\mathrm{pH} 6.4$, with $0.13 \%$ soluble starch as substrate.

Substrate specificity. The following carbohydrates were tested as substrates in the presence of broken-cell supernatant fluid and $0.04 \mathrm{mM}-\left[{ }^{32} \mathrm{P}\right]$ phosphate; the results are expressed relative to that with $0.13 \%$ soluble starch $=100: 0.2 \%$ rice starch, 10 to $30 ; 3.3 \mathrm{mM}$-maltose, 10 to $36 ; 3.3 \mathrm{~mm}$-sucrose, 12 to $220 ; 3.3 \mathrm{~mm}$-glucose, $17 ; 3.3 \mathrm{~mm}$ lactose, $25 ; 3.3 \mathrm{~mm}$-cellobiose, $24 ; 0.06 \%$ inulin, 13 ; no addition, 13 to 23 . The activities in the presence of sucrose were very variable. It is possible that the amount of the enzyme responsible varied in different batches of protozoa. The maximum velocities at infinite phosphate concentration and the $K_{m}$ values (i.e. substrate concentration at which velocity is half the maximum) in the presence of $0.2 \%$ carbohydrate are given in Table 6. Although these experiments were all made with brokencell supernatant fluid as source of enzyme, $60 \%$ of the activity present in a complete protozoal homogenate was in the broken-cell pellet (Table 5). The activity found on incubation of the pellet fraction in the absence of added carbohydrate was only stimulated three-fold by the addition of $0.2 \%$ soluble starch, presumably because of the presence of rice starch grains and protozoal polysaccharide granules in the pellet fraction. The activity of both the supernatant fluid and pellet fractions in presence of $0.2 \%$ soluble starch was decreased by about $20 \%$ at all phosphate concentrations on pre-incubation of the protozoa with 1000 units penicillin $/ \mathrm{ml} .+400 \mu \mathrm{g}$. neomycin sulphate $/ \mathrm{ml}$. for $18 \mathrm{hr}$.

\section{Table 6. Kinetic constants of certain enzymes of Entodinium caudatum}

The enzyme activities of protozoal broken-cell supernatant fluid were measured as described in Methods. To determine the activities present in antibiotic-treated protozoa, the protozoa were harvested from the growth medium and incubated in the presence of 1000 units penicillin $/ \mathrm{ml} .+400 \mu \mathrm{g}$. neomycin sulphate $/ \mathrm{ml}$. for $18 \mathrm{hr}$ before preparation of the broken-cell supernatant fluid. Maximum velocities were measured by extrapolation of a reciprocal plot of velocity/substrate concentration, to infinite substrate concentration. The $K_{m}$ value was the substrate concentration at which the velocity was half the maximum.

Enzyme

$\alpha$ Glucan phosphorylase

Hexokinase

Phosphoglucomutase

Maltase
Substrate

$0.2 \%$ soluble starch, phosphate $0.2 \%$ rice starch, phosphate $0.2 \%$ maltose, phosphate

Glucose, 5 mм ATP

Glucose, 5 mM ATP

Galactose, 5 mM ATP

Glucose-I-phosphate Glucose-I-phosphate Maltose

$\begin{array}{cc}\begin{array}{c}\text { Protozoa } \\ \text { pre-incubated } \\ \text { with } \\ \text { antibiotics }\end{array} & \begin{array}{c}\text { Maximum } \\ \text { velocity } \\ \left(\mu \text { moles } / \mathrm{hr} / 1^{\circ}\right.\end{array} \\ & \text { protozoa) }\end{array}$

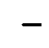

-

$\overline{-}$

$-$

$+$

$-$

$+$

$-$

$$
\begin{gathered}
4 \cdot 1-9.8 * \\
0.53^{*} \\
0.15^{*} \\
1 \cdot 8 \dagger \\
1 \cdot 4 \dagger \\
1 \cdot 2 \dagger \\
4 \cdot 1 \\
6 \cdot 2 \\
22
\end{gathered}
$$
(mM)

* Phosphate esterified at infinite phosphate concentration. † Measured at infinite sugar concentration.

Reaction products. The crude broken-cell supernatant fluid contained an active phosphoglucomutase (see below). After prolonged incubation the products of any reaction in which glucose phosphates were produced were $95 \%$ glucose-6-phosphate 
and $5 \%$ glucose-I-phosphate, which is the equilibrium mixture. To determine which phosphate was formed first during incubation of broken-cell supernatant fluid with soluble starch and [ $\left.{ }^{32} \mathrm{P}\right]$ phosphate, samples were taken at intervals, the phosphate precipitated with fluoride+magnesia mixture and then the glucose phosphates separated by chromatography in solvent $\mathrm{C}$. The position of the $\left[{ }^{32} \mathrm{P}\right]$ phosphates was determined by radioautography and the radioactivity in each measured. After $5 \mathrm{~min}$. incubation $6 \mathrm{I} \%$ of the ${ }^{32} \mathrm{P}$ was associated with the glucose-I-phosphate; this proportion fell progressively until after $3 \mathrm{hr}$ only Io \% was present, the remainder being all associated with the glucose-6-phosphate spot. This is taken as evidence that glucose-Iphosphate was the first product of the reaction and that the ${ }^{32} \mathrm{P}$ was not entering the glucose phosphates by exchange with the $\gamma$-phosphate of adenosine triphosphate (ATP) followed by phosphorylation of glucose to give glucose-6-phosphate.

Hexokinase. Glucokinase (ATP: D-glucose-6-phosphotransferase) activity was measured by the formation of $\left[{ }^{14} \mathrm{C}\right]$ glucose phosphate from $\left[{ }^{14} \mathrm{C}\right]$ glucose in the presence of ATP. In the presence of I mM-glucose and the broken-cell supernatant fluid from $2.7 \times 10^{6}$ protozoa, the reaction was linear for $\mathrm{I} \mathrm{hr}$. Thereafter the rate of hexose phosphate formation decreased markedly and this was associated with the appearance of fructose in the medium. In the absence of ATP the amount of glucose esterified decreased to less than $5 \%$. The optimum value was $\mathrm{pH} 6 \cdot 7$. The maximum velocities and $K_{m}$ values for the hexokinase activity of the broken-cell supernatant fluid from normal and antibiotic treated protozoa are given in Table 6.

In view of the possibility that hexokinase might be involved in the incorporation of $\left[{ }^{14} \mathrm{C}\right]$ glucose by washed protozoa it was necessary to determine whether the pattern of inhibition of the two reactions by other sugars and sugar analogues was the same. For these experiments which were of $30 \mathrm{~min}$. duration $\left[{ }^{14} \mathrm{C}\right]$ glucose was present at $0.5 \mathrm{~mm}$, ATP at $5 \mathrm{~mm}$ and the inhibitors at $25 \mathrm{~mm}$. The results, expressed relative to those in the absence of inhibitor $=100$ were: L-glucose, I00; 3-methylglucose, 100 ; ribose, 100; sorbitol, 96; fructose, 90; mannose, 86; 2-deoxyglucose, 80; maltose, 40; galactose, 38 ; D-glucose, 6 . The decrease in activity in the presence of maltose was probably due to hydrolysis of maltose to glucose as the preparation contained a maltase (see below). These results contrasted with those on the incorporation of glucose by intact protozoa, in that with intact protozoa 2-deoxyglucose was more potent than galactose at low glucose concentration. This suggests that hexokinase did not mediate the incorporation of glucose by intact protozoa. The inhibition of hexokinase activity by galactose was competitive on a reciprocal plot of activity/substrate concentration in the presence and absence of $80 \mathrm{~mm}$-galactose. Galactose was also utilized as a substrate for the hexokinase reaction and the maximum velocity and $K_{m}$ value are given in Table 6.

Phosphoglucomutase. Phosphoglucomutase ( $\alpha$-D-glucose- 1,6-diphosphate : $\alpha$-glucoseI-phosphate phosphotransferase, EC 2.7.5.I) activity was assayed by estimating the amount of reducing sugar, i.e. glucose-6-phosphate, formed on incubation of brokencell supernatant fluid with glucose-I-phosphate. The rate of reaction was constant for $30 \mathrm{~min}$. The kinetic constants are given in Table 6.

Maltase. Maltase ( $\alpha$-D-glucoside glycohydrolase, EC 3.2. I .20) activity was assayed by measuring glucose formation from maltose in presence of broken-cell supernatant fluid by means of glucose oxidase. The kinetic constants are given in Table 6. As the concentration of glucose in the protozoal pool could be controlled in part by an 
inhibitory effect of glucose on the enzyme hydrolysing maltose to glucose, the effect of glucose and other monosaccharides on this reaction was investigated. This was estimated by incubation of broken-cell supernatant fluid with $\left[{ }^{14} \mathrm{C}\right]$ maltose in the presence of different concentrations of $\left[{ }^{22} \mathrm{C}\right]$ glucose or other sugar for $5 \mathrm{~min}$. and then stopping the reaction by immersion in a boiling water bath for $5 \mathrm{~min}$. Samples of the supernatant fluids after removal of the protein by centrifugation were chromatographed in solvent $\mathrm{B}$, the position of the maltose and glucose spots determined by radioautography and the ${ }^{14} \mathrm{C}$ in each estimated by placing a GM tube directly on the paper. From these values the proportion of the maltose hydrolysed to glucose could be calculated. Figure II shows that in the presence of $12 \mathrm{~mm}$-maltose the addition of IO mM-glucose decreased the rate of maltose hydrolysis by $50 \%$. Over the glucose concentration range of 5 to $15 \mathrm{mM}$ (the probable concentration in the freshly harvested protozoon) a change of $\mathrm{I} \mathrm{mM}$ in the glucose concentration altered the rate by 5 to $10 \%$.

Amylase. Since the concentration of glucose in the pool would also depend on the concentration of maltose and the rate of maltose formation from starch, the effect of glucose and maltose on this latter reaction was investigated. The experiment was made in $0.4 \mathrm{ml}$. volumes containing $\left[\mathrm{U}-1{ }^{14} \mathrm{C}\right]$ soluble starch $(0.2 \mu \mathrm{C} ; 7.7 \mu \mathrm{g}$.), broken-cell supernatant fluid from approximately $5 \times 10^{5}$ protozoa and o to $500 \mathrm{~mm}\left[{ }^{12} \mathrm{C}\right]$ glucose or maltose. After incubation for $5 \mathrm{~min}$. the reaction was stopped by immersion of the tubes in boiling water and the precipitate removed by centrifugation. The glucose and maltose were separated from the starch by chromatography in solvent $\mathrm{B}$ and the ${ }^{14} \mathrm{C}$ contents of the compounds measured as described above. The amount of hydrolysis was measured as the ${ }^{14} \mathrm{C}$ present in the two sugars divided by the ${ }^{14} \mathrm{C}$ present in all three compounds. $\left[{ }^{12} \mathrm{C}\right] \mathrm{glucose}$ had little effect on the rate of starch hydrolysis, but small changes in the concentration of $\left[{ }^{2} \mathrm{C}\right]$ maltose had a marked effect. Over the range 5 to $20 \mathrm{mM}$ a change of $\mathrm{I} \mathrm{mM}$ in the maltose concentration altered the rate by 3 to $5 \%$ (Fig. II).

\section{Probable mechanism of starch metabolism}

Although it has been shown above that various enzymes for the metabolism of carbohydrates exist in the cell, it is not clear whether starch was degraded initially by phosphorolysis to glucose-I-phosphate or hydrolysed via maltose to glucose and then phosphorylated to glucose-6-phosphate in the presence of a hexokinase. To elucidate this ${ }^{14} \mathrm{C}$-soluble starch was incubated in salt solution B with broken-cell supernatant fluid in the presence and absence of $6 \mathrm{mM}-\mathrm{ATP}$ and the rate of $\left[{ }^{14} \mathrm{C}\right]$ hexose phosphate formation measured under the two conditions. In the absence of ATP any hexose phosphate must be formed by phosphorolysis of the starch, whereas in the presence of ATP hexose phosphate could also arise by phosphorylation of glucose formed from the starch by hydrolysis.

The experiment was made in $\mathrm{I} \cdot 7 \mathrm{ml}$. volumes containing salt solution $\mathrm{B}, 0 . \mathrm{I} \%\left[{ }^{14} \mathrm{C}-\right]$ soluble starch $\left(0.06 \mu \mathrm{c} / \mathrm{ml}\right.$.) and the broken-cell supernatant fluid from $0.86 \times 10^{6}$ protozoa in the presence or absence of $6 \mathrm{mM}$-ATP. The reaction was stopped by immersing the tubes containing the reaction mixture in boiling water and the protein precipitate then removed by centrifugation. A sample of the supernatant fluid was treated with Dowex 2 (acetate) to remove hexose phosphates which were subsequently eluted by treatment with $\mathrm{N}-\mathrm{HCl}$. To obtain a measure of the amount of 
starch that had been hydrolysed to maltose and glucose, a reducing sugar determination was made on the reaction mixture after removal of the hexose phosphates with the resin. Under the conditions of the reducing sugar assay the extinction obtained per mole of glucose was only i $\%$ less than that obtained per mole of maltose; the results have been calculated as though all the reducing sugar was glucose. Approximately equal quantities of the two sugars were found. In the experiment shown in Fig. I 2 the rate of formation of hexose phosphate in the absence of added ATP was lower than in its presence and had almost ceased after $15 \mathrm{~min}$; in the presence of ATP the reaction was still proceeding after $60 \mathrm{~min}$. These findings suggested that there

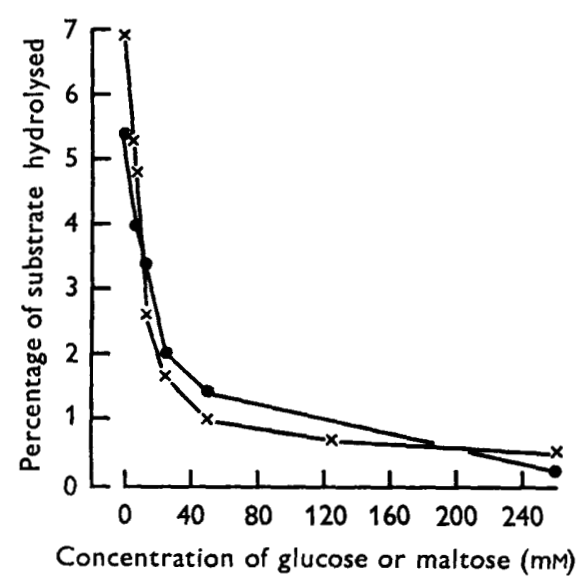

Fig. I I

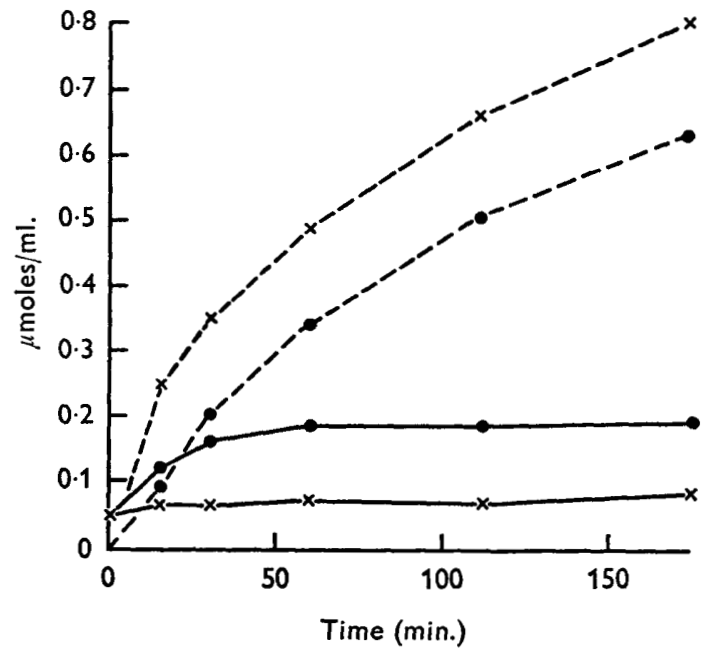

Fig. 12

Fig. I I. Effect of glucose concentration on the hydrolysis of $12 \mathrm{~mm}-\left[\mathrm{U}-{ }^{14} \mathrm{C}\right] \mathrm{maltose}(x-x)$ and of maltose concentration on the hydrolysis of $0.2 \%\left[\mathrm{U}-{ }^{14} \mathrm{C}\right]$ soluble starch by broken-cell supernatant fluid during a $5 \mathrm{~min}$. incubation.

Fig. I2. Effect of 10 mM-ATP on the formation of hexose phosphate $(\longrightarrow)$ and reducing sugars expressed as glucose (- - - ) from $0.017 \%$ [U-14 C]soluble starch by broken-protozoal supernatant fluid. (O), In presence of ATP; $(\times)$, in absence of ATP.

might have been a limited amount of ATP present in the broken-cell supernatant fluid and that this was all utilized in the first I 5 min. in absence of added ATP. The subsequent slow increase in the amount of hexose phosphate formed is presumed to be due to phosphorolysis. It is apparent from these results that, given ATP, the brokencell supernatant fluid converted the glucose in starch to hexose phosphate after hydrolysis to free glucose, and that the rate of starch hydrolysis was greater than the rate of phosphorylation of glucose.

\section{DISCUSSION}

It has been shown that $63 \%$ of the volume of a packed protozoal pad was impermeable to sugars on incubation for a few minutes at $20^{\circ}$. The electron microscope studies on thin sections of Entodinium caudatum reported previously (Coleman \& Hall, I966) showed that the organism was divided into an outer region (ectoplasm) and an inner region (endoplasm). This latter region contained all the rice starch grains which the 
ciliate had engulfed and all the intracellular bacteria. From these findings it is considered likely that the membrane between the endoplasm and the ectoplasm may form the barrier between the regions which are permeable and impermeable to low molecular weight compounds such as sugars. Some information on which of the two regions was freely permeable to sugars was obtained in the investigations of the effect of inhibitors on the incorporation of ${ }^{14} \mathrm{C}$ from $\left[{ }^{14} \mathrm{C}\right]$ glucose. If the endoplasm were freely permeable and the bacteria therein were exposed to the external medium then the degree of inhibition of incorporation of ${ }^{14} \mathrm{C}$ into the bacteria by any reagent should be the same in intact protozoa as in broken protozoa. If it is the ectoplasm which is freely permeable, then the effect of an inhibitor would be more complicated and would depend in part on the effect of the inhibitor on the passage of glucose through the membrane into the endoplasm, and not necessarily on the effect of the inhibitor on the bacteria. The results obtained showed that 2-deoxyglucose and galactose inhibited the incorporation of ${ }^{14} \mathrm{C}$ from $\left[{ }^{14} \mathrm{C}\right]$ glucose by bacteria in intact protozoa by 71 and $29 \%$, respectively, and into washed suspensions of the two most numerous bacteria by 30 and $90 \%$, respectively, i.e. the pattern of inhibition was different. With intact protozoa in the presence of either inhibitor the effect on the incorporation of ${ }^{14} \mathrm{C}$ into the intracellular bacteria was the same as that on the incorporation into the protozoal pool, suggesting that the glucose utilized by the bacteria came from the pool and not from the medium. Both these results supported the view that it was the ectoplasm that was freely permeable. Unfortunately experiments on the effect of inhibitor on broken protozoa that contained intact bacteria showed that although 2-deoxyglucose and galactose gave about $20 \%$ greater inhibition than in intact protozoa, the 2-deoxyglucose was always more effective than galactose. Although this may be interpreted as supporting the view that it was the endoplasm that was permeable, two previously reported findings are not consistent with this. Firstly, the inhibitory effect of a free $\left[{ }^{12} \mathrm{C}\right]$ amino acid on the incorporation of the ${ }^{14} \mathrm{C}$-form of that amino acid from bacterial protein into protozoal protein was related to the rate at which the free amino acid was incorporated by the protozoa (Coleman, 1967a). Secondly, it proved difficult to kill bacteria inside intact protozoa by incubation in the presence of penicillin + neomycin, although the same bacteria were readily killed under the same conditions after protozoal breakage (Coleman, 1962). Therefore, it is considered more likely that it was the ectoplasm that was freely permeable to glucose and other low molecular weight compounds of the medium.

The incorporation of $\left[{ }^{14} \mathrm{C}\right]$ glucose into the protozoal pool consisted of two processes as shown by the break in the curve on the reciprocal plot of incorporation of ${ }^{14} \mathrm{C}$ in a certain time/substrate concentration. At high concentrations, above about $2.5 \mathrm{~mm}$, incorporation was proportional to glucose concentration, had an almost infinite maximum velocity and was not affected by inhibitors of group 2 such as sorbitol. It is therefore considered to be a passive uptake. At low concentrations, the reaction had a finite maximum rate, was more rapid than the passive uptake and was inhibited by inhibitors of group 2. It is therefore assumed to be a process that was dependent upon metabolic processes, i.e. 'active'. Both processes are considered to be operative at all glucose concentrations, but the 'active' process is predominant at low concentrations and the passive at high. If the $\left[{ }^{4} \mathrm{C}\right]$ glucose, in protozoa that had been incubated in the presence of a high concentration of glucose and then washed, was present at its original concentration, it occupied only $5 \%$ of the protozoal volume. This means that 
the passive uptake of glucose must represent penetration into a minor cell compartment and not into the complete endoplasm. However, it is considered likely that the 'active' uptake of glucose was into the endoplasm. As there was no discontinuity in the curve for incorporation of ${ }^{14} \mathrm{C}$ into protozoal polysaccharide on a reciprocal plot of incorporation/substrate concentration, it is postulated that only glucose taken up by the 'active' process can be incorporated into protozoal polysaccharide. If glucose taken up by both processes could be utilized the curve might be expected to show a break at about 2.5 mM. At low glucose concentrations more of the ${ }^{14} \mathrm{C}$ that had been incorporated was present as hexose phosphate than at high concentrations and this would be expected if only the 'active' uptake were into a compartment where further metabolism of the glucose could occur. The finding that at low glucose concentrations 2-deoxyglucose decreased the incorporation of ${ }^{14} \mathrm{C}$ into the pool but had no effect on the distribution of ${ }^{14} \mathrm{C}$ between the various pool constituents is interpreted as showing that glucose is taken up actively as such, and then phosphorylated. If the phosphorylation were obligatory for uptake then 2-deoxyglucose might have a specific effect on the concentration of hexose phosphate. This interpretation is supported by the finding that the hexokinase of the broken protozoal supernatant fluid was not very sensitive to inhibition by 2-deoxyglucose.

The action of iodoacetate in markedly increasing the amount of $\left[{ }^{14} \mathrm{C}\right]$ glucose that could not be removed from the protozoa by washing, without increasing the permeability of the protozoa, was unexpected since it was used in an attempt to inhibit the 'active' uptake of glucose. Since iodoacetate is a metabolic inhibitor then its effect must result from the inhibition of some process such as a metabolic pump for the expulsion of glucose from a cell compartment. If the region of the cell into which glucose penetrated passively were the contractile vacuole then in normal protozoa much of this glucose would be lost by operation of the vacuole during washing of the protozoa. In the presence of iodoacetate the vacuole would be unable to contract and would remain full of glucose. The similar results obtained on incubation of the protozoa at very low salt concentration could be explained by the ectoplasmic/endoplasmic membrane becoming 'leaky', associated with the passage of water into the cell. Glucose would then enter the endoplasm and be trapped there on return of the protozoa to salts of standard concentration.

It has been known for many years (Abou Akkada \& Howard, 1960) that the addition of starch but not glucose to washed protozoal suspensions stimulates gas production. This means that any proposed mechanism of glucose incorporation must explain why exogenous glucose and glucose formed by the hydrolysis of starch grains are metabolized differently. For the reasons given above the passive uptake of glucose is assumed to be into some compartment such as the contractile vacuole, where it is not available for further metabolism. The active incorporation of $\left[{ }^{14} \mathrm{C}\right] \mathrm{glucose}$ is probably a net incorporation of glucose into the endoplasm as no evidence was found for an exchange reaction. The maximum rate of glucose uptake at infinite glucose concentration was $0.046 \mu \mathrm{mole} / \mathrm{hr} / \mathrm{IO}^{6}$ protozoa. As the volume of each protozoon in a packed cell pad was $4.7 \times 10^{4} \mu^{3}$ (Coleman, 1967a) the volume of $10^{6}$ protozoa was $4.7 \times 10^{10} \mu^{3}$, or $0.047 \mathrm{ml}$. If, as shown above, $37 \%$ of this volume was fluid space into which the external medium could not freely penetrate, then the volume of $10^{6}$ protozoa that contained the incorporated glucose was $0.047 \times 0.37=0.017 \mathrm{ml}$. If all the glucose incorporated in I hr remained as free glucose, the concentration at 
the end of that hour would be $0.046 / 0.017=2.7 \mathrm{~mm}$ compared with $14.8 \mathrm{mM}$ present initially in the protozoa as the result of the hydrolysis of engulfed starch grains. It is considered that there would be no net increase in the glucose concentration in the endoplasm due to 'active' uptake of glucose on incubation with say $50 \mathrm{~mm}$-glucose in the presence of antibiotics, for the following reasons. Firstly, since the incorporation quoted above was the maximum at infinite glucose concentration, the actual incorporation would be lower. Secondly, as prolonged incubations must be done in the presence of penicillin + neomycin to prevent bacterial growth, the actual rate of glucose incorporation would be decreased under these conditions. Thirdly, any increase in glucose concentration in the pool would tend to decrease the rate of glucose formation from maltose. Even if the glucose concentration were to rise as the result of uptake of free glucose, the rate of glucose phosphorylation would not rise significantly, because at $\mathrm{I}_{4} .8 \mu \mathrm{moles}$ glucose $/ \mathrm{ml}$. the activity of the hexokinase was $96 \%$ of that at infinite glucose concentration.

The finding that little ${ }^{14} \mathrm{C}$ from $\left[{ }^{[4} \mathrm{C}\right]$ glucose or $\left[{ }^{14} \mathrm{C}\right]$ starch was incorporated into protozoal protein is of considerable importance in considering the over-all metabolism of the rumen. Bryant \& Robinson (1963) showed that many pure strains of rumen bacteria utilized ammonia in preference to amino acids for growth, and when provided with amino acids as sole source of nitrogen incorporated little amino acid-carbon into cellular materials. In contrast, Entodinium caudatum incorporated the amino acids of bacterial protein directly into its protein and showed very limited ability to catabolize amino acids (Coleman, I $967 a, b$ ). This means that if $E$. caudatum is typical of all the Entodiniomorphid protozoa in the rumen, then these protozoa play no role in the synthesis of those 'essential' amino acids commonly present in low concentration in plant proteins.

I wish to thank Mr G. A. Embleton for inserting permanent rumen canulas into the sheep used to provide rumen fluid for the routine maintenance of the protozoa, the members of the Sub-Department of Chemical Microbiology, Biochemistry Department, University of Cambridge, for their helpful advice and criticism, and Miss B. C. Hanzl for valuable technical assistance.

\section{REFERENCES}

ABou AKKaDA, A. R. \& HowARD, B. H. (1960). The biochemistry of rumen protozoa. 3. The carbohydrate metabolism of entodinium. Biochem. J. 76, 445.

Agarwal, D. P., Sanwal, G. G. \& Krishnan, P.S. (1963). Improved paper chromatographic separation of sugar phosphates using borate impregnated paper. Analyst, Lond. 88, 969.

BANDURSKI, R. S. \& AXELROD, B. (195I). The chromatographic identification of some biologically important phosphate esters. J. biol. Chem. 185, 657.

Bryant, M. P. \& Robinson, I. M. (1963). Apparent incorporation of ammonia and amino acid carbon during growth of selected species of ruminal bacteria. J. Dairy Sci. 46, I50.

Coleman, G. S. (1958). Maintenance of oligotrich protozoa from the sheep rumen in vitro. Nature, Lond. 182, I 104.

Coleman, G. S. (1960a). The cultivation of sheep rumen oligotrich protozoa in vitro. J. gen. Microbiol. 22, 555 .

Coleman, G. S. $(1960 b)$. Effect of penicillin on the maintenance of rumen oligotrich protozoa. Nature, Lond. $187,518$.

Coleman, G. S. (1962). The preparation and survival of almost bacteria free suspensions of Entodinium caudatum. J. gen. Microbiol. 28, 27I. 
Coleman, G. S. (1964a). The metabolism of ${ }^{14} \mathrm{C}$-glycine and ${ }^{14} \mathrm{C}$-bicarbonate by washed suspensions of the rumen ciliate Entodinium caudatum. J. gen. Microbiol. 35, 91 .

Coleman, G.S. (1964b). The metabolism of Escherichia coli and other bacteria by the rumen ciliate Entodinium caudatum. J. gen. Microbiol. 37, 209.

Coleman, G. S. (1967a). The metabolism of free amino acids by washed suspensions of the rumen ciliate Entodinium caudatum. J. gen. Microbiol. 47, 433.

Coleman, G. S. $(1967 b)$. The metabolism of the amino acids of Escherichia coli and other bacteria by the rumen ciliate Entodinium caudatum. J. gen. Microbiol. 47, 449.

Coleman, G. S. \& Hall, F. J. (1966). Bacterial feeding by the rumen ciliate Entodinium caudatum. J. gen. Microbiol. 44, iii.

Drxon, M. \& WeBB, E. C. (1964). Enzymes. London: Longmans Green and Co., Ltd.

GuIllaume, J. \& OsteuX, R. (1955). Détermination des acides aliphatiques volatils de $\mathrm{C}_{1}$ à $\mathrm{C}_{6}$ dans les liquids biologiques par chromatographie du papier. C. r. hebd. Séanc. Acad. Sci., Paris 24I, 501 .

HolTER, H. (1965). Passage of particles and macromolecules through cell membranes. Symp. Soc. gen. Microbiol. I5, 89.

Horrocks, R. H. \& MANNING, G. B. (1949). Partition chromatography on paper. Identification of reducing substances in urine. Lancet, $\mathrm{i}, 1042$.

Huggetr, A. St G. \& Nixon, D. A. (1957). Use of glucose oxidase, peroxidase and 0 -dianisidine in determination of blood and urinary glucose. Lancet, ii, 368.

LeloIR, L. F. \& CARDINI, C. E. (1957). Characterization of phosphorus compounds by acid lability. In Methods of Enzymology. Ed. by S. P. Colowick and N. O. Kaplan, Vol. 3, p. 840.

OXFORD, A. E. (1951). The conversion of certain soluble sugars to a glucosan by holotrich ciliates in the rumen of sheep. J. gen. Microbiol. 5,83 .

Park, J. T. \& Johnson, M. J. (1949). A submicrodetermination of glucose. J. biol. Chem. r81, I49.

Potter, V. R. \& ElvehJem, C. A. (1936). A modified method for the study of tissue oxidations. J. biol. Chem. Ir4, 495.

Roberts, R. B., Abelson, P. H., Cowie, D. B., Bolton, E. T. \& Britten, R. J. (1955). Studies on biosynthesis in Escherichia coli. Publs. Carnegie Instn No. 607.

SMIrH, I. (1960). Chromatographic and Electrophoretic Techniques. London: William Heinemann Medical Books, Ltd.

Sugden, B. (I953). The cultivation and metabolism of oligotrich protozoa from the sheep's rumen. J. gen. Microbiol. 9, 44.

WhITE, R. W. (I966). Bacterial population of the rumen ciliate Entodinium caudatum cultured in vitro. J. gen. Microbiol. 42, xii. 